University of Nebraska - Lincoln

DigitalCommons@University of Nebraska - Lincoln

\title{
Chemistry and Microbial Functional Diversity Differences in Biofuel Crop and Grassland Soils in Multiple Geographies
}

\author{
Lidia S. Watrud \\ United States Environmental Protection Agency, watrud.lidia@epa.gov \\ Jay R. Reichman \\ United States Environmental Protection Agency \\ Michael A. Bollman \\ United States Environmental Protection Agency \\ Bonnie M. Smith \\ United States Environmental Protection Agency \\ E. Henry Lee \\ United States Environmental Protection Agency \\ See next page for additional authors
}

Follow this and additional works at: https://digitalcommons.unl.edu/usdaarsfacpub

Watrud, Lidia S.; Reichman, Jay R.; Bollman, Michael A.; Smith, Bonnie M.; Lee, E. Henry; Jastrow, Julie D.; Casler, Michael D.; Collins, Harold P.; Fransen, Steven; Mitchell, Robert B.; Owens, Vance N.; Bean, Brent; Rooney, William L.; Tyler, Donald D.; and King, George A., "Chemistry and Microbial Functional Diversity Differences in Biofuel Crop and Grassland Soils in Multiple Geographies" (2013). Publications from USDAARS / UNL Faculty. 1326.

https://digitalcommons.unl.edu/usdaarsfacpub/1326

This Article is brought to you for free and open access by the U.S. Department of Agriculture: Agricultural Research Service, Lincoln, Nebraska at DigitalCommons@University of Nebraska - Lincoln. It has been accepted for inclusion in Publications from USDA-ARS / UNL Faculty by an authorized administrator of DigitalCommons@University of Nebraska - Lincoln. 


\section{Authors}

Lidia S. Watrud, Jay R. Reichman, Michael A. Bollman, Bonnie M. Smith, E. Henry Lee, Julie D. Jastrow, Michael D. Casler, Harold P. Collins, Steven Fransen, Robert B. Mitchell, Vance N. Owens, Brent Bean, William L. Rooney, Donald D. Tyler, and George A. King 


\title{
Chemistry and Microbial Functional Diversity Differences in Biofuel Crop and Grassland Soils in Multiple Geographies
}

\author{
Lidia S. Watrud • Jay R. Reichman • Michael A. Bollman • Bonnie M. Smith • \\ E. Henry Lee • Julie D. Jastrow • Michael D. Casler • Harold P. Collins • \\ Steven Fransen • Robert B. Mitchell • Vance N. Owens • Brent Bean • \\ William L. Rooney • Donald D. Tyler • George A. King
}

Published online: 21 November 2012

(C) Springer Science+Business Media New York (outside the USA) 2012

This article is a U.S. government work, and is not subject to copyright in the United States.

\begin{abstract}
We obtained soil samples from geographically diverse switchgrass (Panicum virgatum L.) and sorghum (Sorghum bicolor L.) crop sites and from nearby reference grasslands and compared their edaphic properties, microbial gene diversity and abundance, and active microbial biomass content. We hypothesized that soils under switchgrass, a perennial, would be more similar to reference grassland soils than sorghum, an annual crop. Sorghum crop soils had significantly higher $\mathrm{NO}_{3}{ }^{-}-\mathrm{N}, \mathrm{NH}_{4}{ }^{+}-\mathrm{N}, \mathrm{SO}_{4}{ }^{2-}-\mathrm{S}$, and $\mathrm{Cu}$ levels than grassland soils. In contrast, few significant differences in soil chemistry were observed between switchgrass crop and
\end{abstract}

L. S. Watrud $(\bowtie) \cdot J$. R. Reichman • M. A. Bollman •

B. M. Smith • E. H. Lee

United States Environmental Protection Agency,

200 SW 35th Street,

Corvallis 97333, OR, USA

e-mail: watrud.lidia@epa.gov

\section{J. D. Jastrow}

Argonne National Laboratory Biosciences Division,

9700 South Cass Avenue,

Argonne 60439, IL, USA

\section{D. Casler}

United States Department of Agriculture,-ARS, US Dairy Forage

Research Center, 1925 Linden Drive,

Madison 53706, WI, USA

\section{H. P. Collins}

United States Department of Agriculture-ARS, Vegetable and

Forage Crops Research Unit, 24106 N. Bunn Road,

Prosser 99350, WA, USA

\section{S. Fransen}

Washington State University Irrigated Agriculture Research and

Extension Center, 24106 N. Bunn Road,

Prosser 99350, WA, USA grassland soils. Active bacterial biomass was significantly lower in sorghum soils than switchgrass soils. Using GeoChip 4.0 functional gene arrays, we observed that microbial gene diversity was significantly lower in sorghum soils than grassland soils. Gene diversity at sorghum locations was negatively correlated with $\mathrm{NO}_{3}{ }^{-}-\mathrm{N}, \mathrm{NH}_{4}{ }^{+}-\mathrm{N}$, and $\mathrm{SO}_{4}{ }^{2-}-\mathrm{S}$ in $\mathrm{C}$ and $\mathrm{N}$ cycling microbial gene categories. Microbial gene diversity at switchgrass sites varied among geographic locations, but crop and grassland sites tended to be similar. Microbial gene abundance did not differ between sorghum crop and grassland soils, but was generally lower in

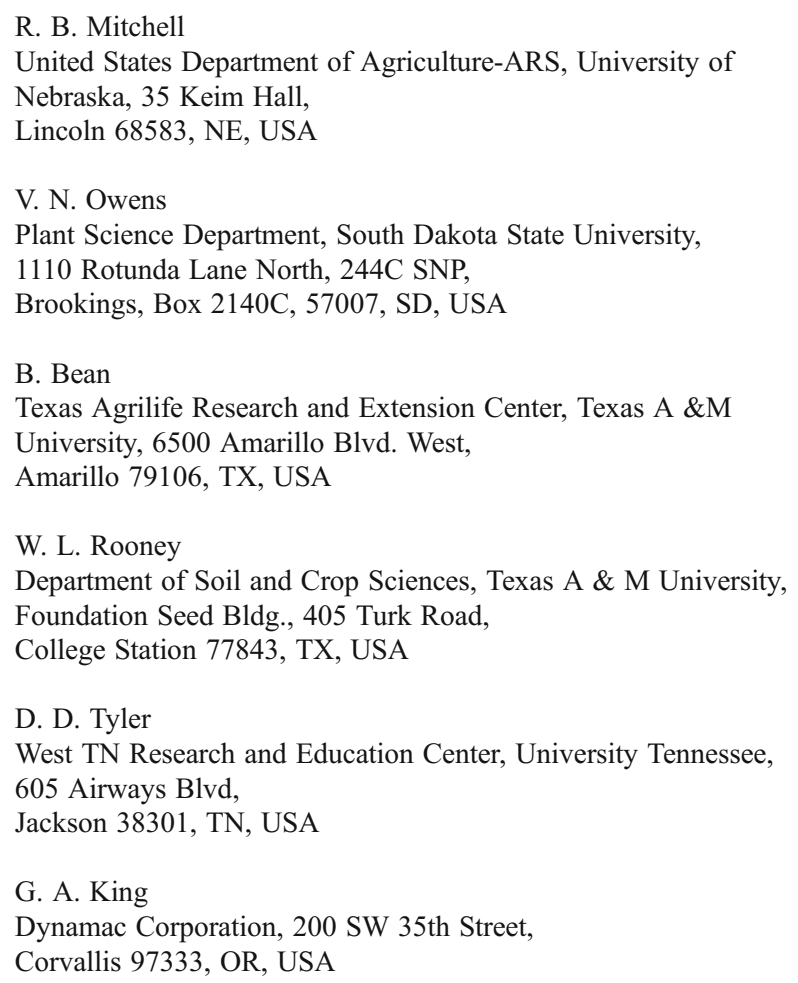


switchgrass crop soils compared to grassland soils. Our results suggest that switchgrass has fewer adverse impacts on microbial soil ecosystem services than cultivation of an annual biofuel crop such as sorghum. Multi-year, multi-disciplinary regional studies comparing these and additional annual and perennial biofuel crop and grassland soils are recommended to help define sustainable crop production and soil ecosystem service practices.

Keywords Switchgrass $\cdot$ Sorghum $\cdot$ GeoChip $\cdot$ Functional gene array $\cdot$ Soil ecosystem services

\section{Introduction}

Second-generation lignocellulosic biofuel sources such as dedicated biomass crops, forestry and agricultural wastes are of interest as renewable sources of energy [1-6]. They are also of interest to decrease our national dependence on foreign petrochemicals and to mitigate global climate change effects [7]. Since many of the proposed lignocellulosic biofuel species are non-food perennial grasses, economic savings are anticipated to result from the lower input costs for tillage, fertilizers, and other crop chemicals, as compared to annual food crops such as corn. The lower inputs for perennial grasses as compared to annual crops are anticipated to provide long-term ecological benefits relating to biodiversity of plants and soil microbes and their associated ecosystem services, including increased soil organic matter content, reduced soil erosion, and improved surface and groundwater quality [8-14]. The primary objectives of our study were to identify the chemical and biological characteristics of soils associated with cultivation of the biofuel crop candidates switchgrass (Panicum virgatum L.) and sorghum (Sorghum bicolor L.) in diverse geographic locations in the USA, and to compare them to nearby perennial grassland reference soils. Availability of such information will help inform land management decisions to select and maximize biofuel crop production practices and to sustain or enhance desired ecosystem services such as carbon sequestration, pollutant degradation, the functional and taxonomic diversity of beneficial soil biota, and availability of soil nutrients to plants.

Our multidisciplinary approach involved the use of microbiological, chemical, and molecular methods to analyze soil microbial community responses to land use change [15-22]. We chose to evaluate microbial functional gene diversity rather than taxonomic diversity since multiple microbial taxa often carry out the same ecological functions. We employed a combination of standard chemical and microscopy-based biological methods and a functional gene array (FGA) approach to identify potential soil chemical and physical factors and microbial genes involved in key soil ecosystem services such as $\mathrm{C}$ utilization, $\mathrm{N}$ cycling, $\mathrm{P}$ cycling, and S utilization. The FGA approach we used [23] contrasts with high throughput rRNA sequencing approaches that can result in the identification of taxa [18, 24-26] and also with mRNA-enriched environmental functional gene microarrays that can be used to profile gene transcripts [27]; it allowed us to identify potential differences in functional diversity as well as relative abundance of microbial functional genes in regional crop soil and nearby non-crop perennial grassland soil samples. Differences in the abundance and diversity of functional genes were proposed to serve as a means of identifying potential indicators of key ecosystem services such as $\mathrm{C}$ and $\mathrm{N}$ cycling in soil that might be impacted by the growth of annual and perennial biofuel crops such as sorghum and switchgrass.

Our field survey design included sampling replicate fields or plots in diverse geographic growing areas for the two types of crops, as well as in nearby perennial generally non-cultivated grassland reference areas, that are referred to hereafter as "grasslands." This was by intent a design distinct from studies in which sampling occurs within a given geographic locale or region on one type of soil, rather than in multiple geographic areas that may contain diverse types or series of soils. We proposed that if differences were similar between crop and grassland areas in multiple geographies and latitudes on multiple soil series, the findings would be of broader interest and potential applicability than observations that were unique to or based on a given locale or soil series. The major objectives of these studies were to test the hypotheses that (1) soil from a perennial crop field such as switchgrass would tend to be more similar to nearby grassland soils than would be soil from an annual crop such as sorghum and (2) that trend would be observed in multiple geographies and types of soils.

\section{Materials and Methods}

\section{Collection of Soil Samples}

Six sets of soil samples were taken from switchgrass fields and associated nearby grasslands in IL, WI, NE, SD, WA, and in the case of TN, from long-term pastures derived from historic oak-hickory forest (Tables 1 and 2). Three additional sets of soil samples were taken from sorghum fields and nearby grasslands in WA, the TX panhandle, and East TX. As shown in Table 2, agronomic practices such as tillage, irrigation, and the amounts and types of $\mathrm{N}$ fertilizer varied widely by crop and geographic location. At all locations, switchgrass had been grown as a perennial biofuel crop for the prior 2-8 years, while sorghum was grown in an annual rotation with various grain, legume, or other food, feed, or 
Table 1 Site locations and soils

\begin{tabular}{|c|c|c|c|c|c|c|c|}
\hline Code & Site type & City, state & Latitude & Longitude & Elevation (m) & Soil texture & Soil series \\
\hline TX-Ac1 & Sorghum & Bushland, TX & 35.204883 & -102.045098 & 1,164 & Silty clay loam & Pantex \\
\hline TX-Ac2 & Sorghum & Wildorado, TX & 35.146440 & -102.202568 & 1,176 & Clay loam & Pullman \\
\hline TX-Ac3 & Sorghum & Canyon, TX & 35.027687 & -101.936193 & 1,110 & Clay loam & Pullman \\
\hline TX-An1 & Native & Bushland, TX & 35.214075 & -102.046675 & 1,157 & Silty clay loam; clay loam & Pantex; Pullman \\
\hline TX-An2 & Native & Wildorado, TX & 35.145782 & -102.194188 & 1,176 & Clay loam & Pullman \\
\hline TX-An3 & Native & Canyon, TX & 35.012035 & -101.936298 & 1,106 & Clay loam & Pullman \\
\hline TX-Cc1 & Sorghum & College Station, TX & 30.549433 & -96.439083 & 69 & Clay & Belk \\
\hline TX-Cc2 & Sorghum & College Station, TX & 30.549483 & -96.431817 & 68 & Clay & Belk \\
\hline TX-Cc3 & Sorghum & College Station, TX & 30.540367 & -96.423250 & 67 & Clay & Ships \\
\hline TX-Cn1 & Native & College Station, TX & 30.533350 & -96.420000 & 68 & Clay & Belk \\
\hline $\mathrm{TX}-\mathrm{Cn} 2$ & Native & College Station, TX & 30.528483 & -96.411650 & 66 & Clay & Ships \\
\hline TX-Cn3 & Native & College Station, TX & 30.553917 & -96.428583 & 67 & Clay & Ships \\
\hline WA-Oc1 & Sorghum & Othello, WA & 46.799700 & -119.041717 & 371 & Silt loam & Shano \\
\hline WA-Oc2 & Sorghum & Othello, WA & 46.789567 & -119.039467 & 367 & Silt loam & Shano \\
\hline WA-Oc3 & Sorghum & Othello, WA & 46.789283 & -119.038883 & 365 & Silt loam & Shano \\
\hline WA-On1 & Native & Othello, WA & 46.782033 & -119.031167 & 362 & Silt loam & Shano \\
\hline WA-On2 & Native & Othello, WA & 46.781200 & -119.031067 & 361 & Silt loam & Shano \\
\hline WA-On3 & Native & Connell, WA & 46.702283 & -119.011233 & 290 & Silt loam & Prosser-Starbuck \\
\hline WA-Pc1 & Switchgrass & Paterson, WA & 45.940781 & -119.496528 & 128 & Loamy sand & Quincy \\
\hline WA-Pc2 & Switchgrass & Paterson, WA & 45.940373 & -119.496847 & 129 & Loamy sand & Quincy \\
\hline WA-Pc3 & Switchgrass & Paterson, WA & 45.939782 & -119.497413 & 126 & Loamy sand & Quincy \\
\hline WA-Pn1 & Native & Paterson, WA & 45.938915 & -119.498461 & 127 & Loamy sand & Quincy \\
\hline WA-Pn2 & Native & Paterson, WA & 45.938757 & -119.497789 & 126 & Loamy sand & Quincy \\
\hline WA-Pn3 & Native & Paterson, WA & 45.938372 & -119.496857 & 127 & Loamy sand & Quincy \\
\hline WIc1 & Switchgrass & Arlington, WI & 43.29963 & -89.35562 & 317 & Silt loam & Plano \\
\hline WIc2 & Switchgrass & Arlington, WI & 43.30054 & -89.34676 & 316 & Silt loam & Plano \\
\hline WIc3 & Switchgrass & Sauk City, WI & 43.34632 & -89.73866 & 269 & Silt loam & Richwood \\
\hline WIn1 & Native & Arlington, WI & 43.34399 & -89.30884 & 311 & Fine sandy loam & Sisson \\
\hline WIn2 & Native & Wyocena, WI & 43.45897 & -89.33047 & 284 & Fine sandy loam & Wyocena \\
\hline WIn3 & Native & Sauk City, WI & 43.29248 & -89.78944 & 242 & Loamy sand & Gotham \\
\hline ILc1 & Switchgrass & Batavia, IL & 41.841983 & -88.229850 & 226 & Silt loam & Grays \\
\hline ILc2 & Switchgrass & Batavia, IL & 41.841367 & -88.229350 & 226 & Silt loam & Grays \\
\hline ILc3 & Switchgrass & Batavia, IL & 41.840350 & -88.230850 & 226 & Silt loam & Grays \\
\hline ILn1 & Native & Batavia, IL & 41.851850 & -88.211733 & 222 & Silt loam & Markham \\
\hline ILn2 & Native & Batavia, IL & 41.850800 & -88.211817 & 221 & Silty clay loam & Drummer \\
\hline ILn3 & Native & Batavia, IL & 41.861667 & -88.252483 & 226 & Silt loam & Mundelein \\
\hline ILr1 & Restored & Batavia, IL & 41.841017 & -88.245217 & 226 & Silt loam & Grays \\
\hline ILr2 & Restored & Batavia, IL & 41.843067 & -88.267300 & 231 & Silt loam & Ozaukee \\
\hline ILr3 & Restored & Batavia, IL & 41.840500 & -88.274000 & 233 & Silt loam & Wauconda \\
\hline SDc1 & Switchgrass & Colman, SD & 44.025589 & -96.844843 & 518 & Silty clay loam & Wentworth-Egan \\
\hline SDc2 & Switchgrass & Bristol, SD & 45.275761 & -97.837151 & 520 & Loam & Buse-Barnes \\
\hline SDn1 & Native & Colman, SD & 44.027352 & -96.850980 & 518 & Silty clay loam/loam & Egan-Ethan \\
\hline SDn2 & Native & Bristol, SD & 45.329295 & -97.837024 & 528 & Loam/silty clay loam & Forman-Buse-Parnell \\
\hline $\mathrm{TNc} 1$ & Switchgrass & Milan, TN & 35.944008 & -88.711956 & 114 & Silt loam & Providence \\
\hline $\mathrm{TNc} 2$ & Switchgrass & Milan, TN & 35.942097 & -88.706908 & 113 & Silt loam & Collins \\
\hline $\mathrm{TNc} 3$ & Switchgrass & Milan, TN & 35.925647 & -88.716914 & 128 & Silt loam & Grenada \\
\hline TNn1 & Pasture & Milan, TN & 35.897522 & -88.719364 & 140 & Silt loam & Lexington \\
\hline TNn2 & Pasture & Milan, TN & 35.871639 & -88.731769 & 138 & Silt loam & Lexington \\
\hline TNn3 & Pasture & Milan, TN & 35.901983 & -88.731911 & 122 & Silt loam & Falaya \\
\hline
\end{tabular}


Table 1 (continued)

\begin{tabular}{|c|c|c|c|c|c|c|c|}
\hline Code & Site type & City, state & Latitude & Longitude & Elevation (m) & Soil texture & Soil series \\
\hline NEc1 & Switchgrass & Mead, NE & 41.153117 & -96.447567 & 354 & Silt loam & Fillmore \\
\hline $\mathrm{NEc} 2$ & Switchgrass & Mead, NE & 41.168217 & -96.411983 & 351 & Silty clay loam & Yutan \\
\hline NEn1 & Native & Lincoln, NE & 40.869350 & -96.806717 & 400 & Clay loam & Pawnee \\
\hline
\end{tabular}

Soil texture and series are from the NRCS Web Soil Survey: http://websoilsurvey.nrcs.usda.gov/app/

fiber crops. For all locations, nine soil cores (approximately $2.5 \mathrm{~cm}$ wide and $15 \mathrm{~cm}$ deep) were to be collected from each of three spatially distinct biofuel feedstock (switchgrass or sorghum) sites preferably greater than 0.2 ha in size, and also from three nearby grassland sites that contained some native plants and had similar types of soils. The samples

Table 2 Agronomic practices

\begin{tabular}{|c|c|c|c|c|c|}
\hline Code & Crop & Cultivar & Crop rotation history & Fertilization/hectare & Irrigation \\
\hline TX-Ac1 & Sorghum & Forage & $\begin{array}{l}\text { Sorghum }>>\text { wheat }>>\text { wheat }>> \\
\text { fallow }\end{array}$ & $\begin{array}{l}33,626 \mathrm{~kg} \text { manure every } 2 \text { years, } \\
140 \mathrm{~kg} \mathrm{~N} \text { as } \mathrm{NH}_{3}\end{array}$ & Full \\
\hline TX-Ac2 & Sorghum & Forage & Wheat $>>$ sorghum $>>$ fallow & See TX-Ac1 & Furrow; full \\
\hline TX-Ac3 & Sorghum & Forage & Wheat $>>$ sorghum $>>$ fallow & See TX-Ac1 & Row water \\
\hline TX-Cc1 & Sorghum & Forage & Sorghum/cotton rotation & $\begin{array}{r}168 \mathrm{~kg} 10-34-0 \text { preplant plus } 4 \mathrm{~kg} \\
\text { zinc; } 112 \mathrm{~kg} 32-0-0 \text { side dressed }\end{array}$ & $\begin{array}{l}\text { Furrow; limited to } \\
\text { pre-flowering }\end{array}$ \\
\hline TX-Cc2 & Sorghum & Forage & Sorghum/cotton rotation & See $T x-C c 1$ & See TX-Cc1 \\
\hline TX-Cc3 & Sorghum & Grain & Sorghum/cotton rotation & See $T x-C c 1$ & See TX-Cc1 \\
\hline WA-Oc1 & Sorghum & Sugar Drip & $\begin{array}{l}\text { 2008: flax and potatoes; 2009: } \\
\text { wheat and beans }\end{array}$ & 2010: $224-168-168$ & Rill; $70 \%$ ET \\
\hline WA-Oc2 & Sorghum & Sugar Drip & $\begin{array}{l}\text { 2008: flax and potatoes; 2009: } \\
\text { wheat and beans }\end{array}$ & 2010: $224-168-168$ & Rill; $50 \%$ ET \\
\hline WA-Oc3 & Sorghum & Sugar Drip & $\begin{array}{l}\text { 2008: flax and potatoes; 2009: } \\
\text { wheat and beans }\end{array}$ & 2010: $224-168-168$ & Rill; $30 \%$ ET \\
\hline WA-Pc1 & Switchgrass & Shawnee & $\begin{array}{l}\text { Leveled in } 2006 \text { for irrigation } \\
\text { center pivot, leaving the } \\
\text { subsoil as the new surface; } \\
\text { 2007: wheat; 2008: } \\
\text { switchgrass (perennial) }\end{array}$ & $\begin{array}{l}112 \mathrm{~kg} \mathrm{~N} / \text { year; } 336 \mathrm{~kg} \mathrm{P}_{2} \mathrm{O}_{5} / \text { year; } \\
168 \mathrm{~kg} \mathrm{SO} \text { /year; } 336 \mathrm{~kg} \mathrm{~K}_{2} \mathrm{O} / \text { year }\end{array}$ & $\begin{array}{l}\text { Center pivot } \\
\sim 91 \mathrm{~cm} / \text { year }\end{array}$ \\
\hline WA-Pc2 & Switchgrass & Shawnee & See Wa-Pc1 & See WA-Pc1 & See WA-Pc1 \\
\hline WA-Pc3 & Switchgrass & Shawnee & See Wa-Pc1 & See WA-Pc1 & See WA-Pc1 \\
\hline WIc1 & Switchgrass & Shawnee & Corn/soybean, 7 years switchgrass & $336 \mathrm{~kg} \mathrm{NH}_{4} \mathrm{NO}_{3}$ per year & None \\
\hline WIc2 & Switchgrass & Hiawatha & $\begin{array}{l}4 \text { years grass, } 2 \text { years soybean, } \\
5 \text { years switchgrass }\end{array}$ & $336 \mathrm{~kg} \mathrm{NH}_{4} \mathrm{NO}_{3}$ per year & None \\
\hline WIc3 & Switchgrass & Cave-in-Rock & Corn/soybean, 7 years switchgrass & $112 \mathrm{~kg} \mathrm{NH}_{4} \mathrm{NO}_{3}$ per year & None \\
\hline ILc1 & Switchgrass & Cave-in-Rock & $\begin{array}{l}\text { First cultivated mid-1800s; } \\
\text { converted from row crop } \\
\text { to c3 pasture grasses in } 1971 \\
\text { but not grazed after } \\
1972 \text { or } 1973 \text {; switchgrass } \\
\text { planted in } 2008\end{array}$ & $\begin{array}{l}67 \mathrm{~kg} \mathrm{~N} / \text { year as urea beginning } \\
\text { June } 2009\end{array}$ & None \\
\hline ILc2 & Switchgrass & Cave-in-Rock & See ILc1 & See ILc1 & None \\
\hline ILc3 & Switchgrass & Cave-in-Rock & See ILc1 & See ILc1 & None \\
\hline SDc1 & Switchgrass & $\mathrm{NE}-28$ & Third year switchgrass & 2005-present: no fertilizer & None \\
\hline SDc2 & Switchgrass & & $\begin{array}{l}\text { 2005-2007: soybean; 2008-present: } \\
\text { switchgrass }\end{array}$ & See SDc1 & None \\
\hline $\mathrm{TNc} 1$ & Switchgrass & Alamo & 7 years switchgrass & $67 \mathrm{kgN} /$ year & None \\
\hline $\mathrm{TNc} 2$ & Switchgrass & Alamo & 7 years switchgrass & $67 \mathrm{kgN} /$ year & None \\
\hline $\mathrm{TNc} 3$ & Switchgrass & Alamo & 7 years switchgrass & $67 \mathrm{kgN} /$ year & None \\
\hline NEc1 & Switchgrass & Shawnee & Seeded in 2006 & $67 \mathrm{kgN}$ in spring 2010 & None \\
\hline $\mathrm{NEc} 2$ & Switchgrass & Cave-in-Rock & Seeded in 1998 & $112 \mathrm{kgN} /$ year & None \\
\hline
\end{tabular}


were collected during the 2010 growing season around the time of crop flowering. For fields $>0.2$ ha, soil cores were collected at 5-m intervals along two perpendicular transects that intersected at their centers; for smaller sampling areas, a central transect and shorter sampling intervals were used. Soil cores were kept on ice during the collection day and also during shipping to the United States Environmental Protection Agency Laboratory in Corvallis, OR. Corers were cleaned with disposable disinfesting wipes (Clorox Company, Oakland, CA) between sampling sites; alternatively, fresh corers were used at each sampling location.

The soil series at each of the regional sampling locations are shown in Table 1. Figure 1 shows switchgrass and sorghum crop sites that were sampled in IL and TX (Fig. 1a, b), as well as reference grassland sites that were sampled such as an oak savannah in WI (Fig. 1c) and short grass prairie in TX (Fig. 1d) near switchgrass and sorghum sites. The broad range of grasslands that were sampled is further illustrated in (Fig. 1e) a tall grass prairie in the upper
Midwest and (Fig. 1f) sagebrush steppe in the Pacific Northwest. Cropping history and agronomic practices for sorghum and switchgrass cultivated crop sites are summarized in Table 2. Edaphic properties are provided in Tables 1, 3, 4, and 5 .

\section{Compositing and Subsampling of Soil Samples}

Following their arrival in Corvallis, nine cores from each crop and reference grassland site were homogenized by mixing for 5 min with a Hobart mixer (Model D300, Hobart Corp., Troy, $\mathrm{OH})$; the Hobart mixing bowl was sanitized with a disinfesting wipe following homogenization of each group of nine soil cores. Composited samples were divided into portions for moisture determinations ( $5 \mathrm{~g})$, soil chemical analyses (250 g), DNA extraction (two 10-g aliquots), and for determinations of active bacterial and fungal biomass $(250 \mathrm{~g})$. Samples for DNA analyses were stored at $-80{ }^{\circ} \mathrm{C}$; samples for chemical, soil bacterial, and fungal
Fig. 1 Photographs taken at times of soil sampling in 2010 at switchgrass (a) and sorghum (b) crop sites, respectively, in IL and TX. Grassland sampling sites are shown for an oak savannah site in WI (c) a short grass prairie site in the TX panhandle (d) a remnant tall grass prairie site in IL (e) and a sagebrush steppe site in WA (f)
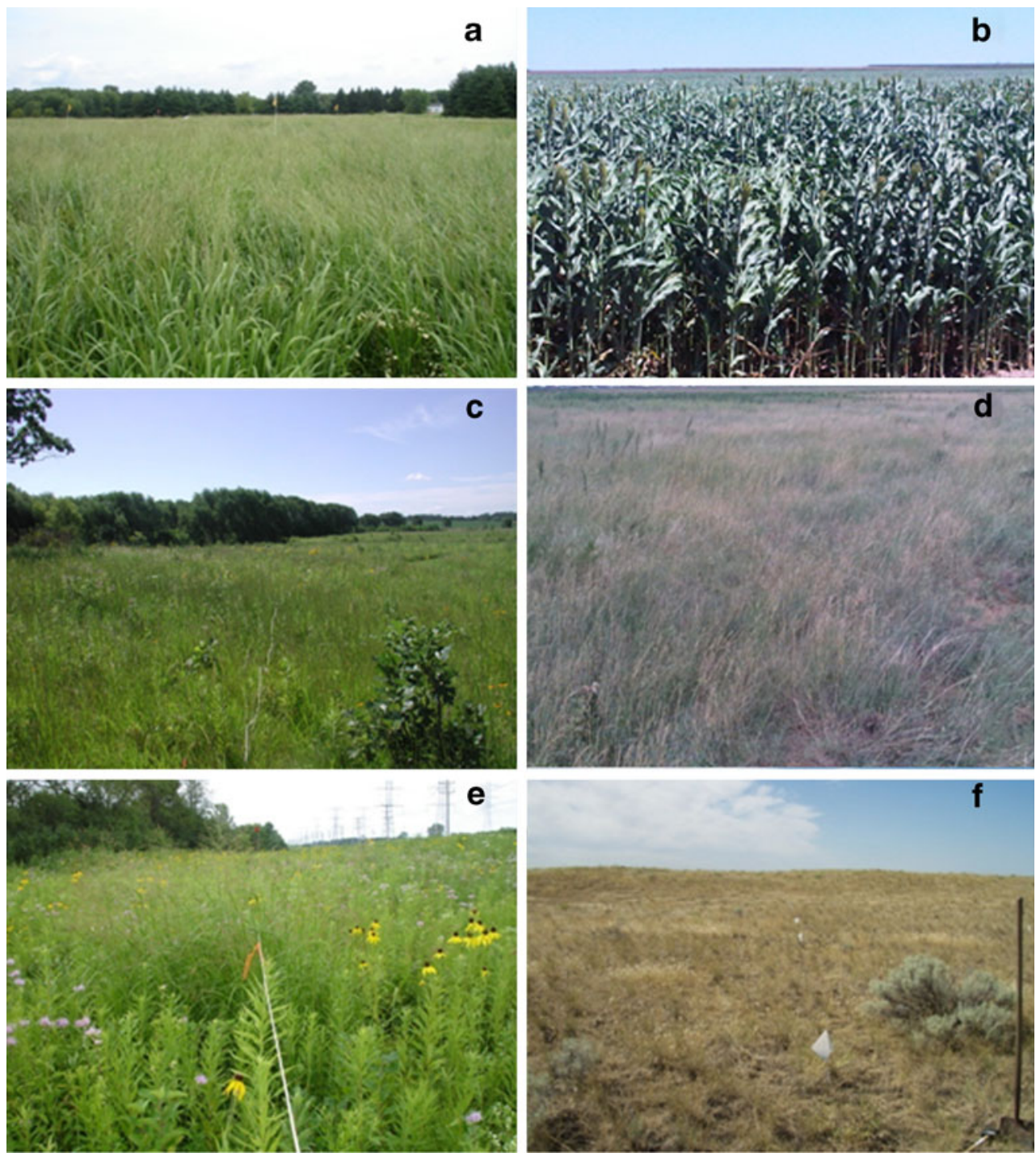
biomass were stored at $4{ }^{\circ} \mathrm{C}$ until delivery (within $48 \mathrm{~h}$ of receipt in Corvallis) to local testing labs. Soil moisture determinations were made gravimetrically, based on differences in the fresh and dry weights of samples dried at $105^{\circ} \mathrm{C}$ in a Blue $\mathrm{M}$ oven (Model POM-326E, Thermal Product Solutions, New Columbia, PA).

\section{Soil Chemical Analyses}

Soil chemical analyses were conducted by the Central Analytical Laboratory at Oregon State University [28] on soil samples that were air-dried at room temperature $\left(22^{\circ} \mathrm{C}\right)$ for approximately 1 week. A subsample of each composited soil sample was extracted with a DTPA extraction solution [0.05 M DTPA (diethylenetriaminepentaacetic acid), $0.1 \mathrm{M}$ triethanolamine, and $0.01 \mathrm{M} \mathrm{CaCl}_{2}$ ], and concentrations of the elements $(\mathrm{B}, \mathrm{Ca}, \mathrm{Cu}, \mathrm{Fe}, \mathrm{K}, \mathrm{Mg}, \mathrm{Mn}$, and $\mathrm{Zn}$ ) were determined using a Perkin Elmer Optima 3000DV inductively coupled plasma optical emission spectrometer with a diode array detector. Similarly, ammonium $\left(\mathrm{NH}_{4}{ }^{+}-\mathrm{N}\right)$ and nitrate $\left(\mathrm{NO}_{3}{ }^{-}-\mathrm{N}\right)$, following extraction with $2 \mathrm{M}$ potassium chloride $(\mathrm{KCl})$, and $\mathrm{P}$, following Bray $\mathrm{P} 1$ extraction, were analyzed on an Alpkem RFA300, and total $\% \mathrm{C}$ and $\% \mathrm{~N}$ were analyzed on a Leco CNS-2000 Macro Analyzer. Sulfate concentration was determined using a Dionex IC 2000 following extraction with calcium dihydrogen phosphate $\left(\mathrm{Ca}\left(\mathrm{H}_{2} \mathrm{PO}_{4}\right) 2 \cdot \mathrm{H}_{2} \mathrm{O}\right)$. Soil particle size distributions (percent sand, percent silt, and percent clay) were estimated by using data from the United States Department of Agriculture Natural Resources Conservation Service (http://websoil survey.nrcs.usda.gov/app/HomePage.htm) for the soil series at each of the regional crop and reference grassland sampling sites.

\section{Active Bacterial and Fungal Biomass}

Active bacterial and fungal biomass was determined by Soil Foodweb, Inc. Corvallis, OR. Extracts of soil stored at $4{ }^{\circ} \mathrm{C}$ were stained with fluorescein diacetate, a substrate that binds and fluoresces to the metabolically active bacteria and fungi $[29,30]$. Brightfield microscopy was used to enumerate bacteria and to measure the widths and lengths of fungal hyphae. Calculated biovolumes were then used to estimate active bacterial and fungal biomass values [31].

\section{Soil Community DNA Isolation}

Soil community DNA extractions for GeoChip 4.0 [32] FGA analyses were carried out at the United States Environmental Protection Agency laboratory in Corvallis, OR. Genomic DNA was extracted from 4-5 g of each soil sample using PowerMax Soil DNA Isolation Kits (MO BIO Laboratories Inc., Carlsbad, CA). The manufacturer's protocol was followed with the following exceptions: (a) the centrifugal spin speed was increased to $4000 \times g$ for the ethanol wash steps, (b) an additional wash step using $10 \mathrm{ml} 95 \%$

Table 3 Soil $\mathrm{pH}$, carbon, nitrogen, and soil physical properties (mean $\pm \mathrm{SE}$ ) at sampling locations

\begin{tabular}{|c|c|c|c|c|c|c|c|c|c|}
\hline Location & Land use & $\mathrm{pH}$ & $\% \mathrm{OM}$ & $\% \mathrm{C}$ & $\% \mathrm{~N}$ & Soil moisture (\%) & Sand $(\%)$ & Silt $(\%)$ & Clay $(\%)$ \\
\hline \multirow[t]{2}{*}{ TX-A } & Sorghum & $7.8 \pm 0.1$ & $2.8 \pm 0.3$ & $1.1 \pm 0.2$ & $0.12 \pm 0.02$ & $13.2 \pm 2.7$ & 27 & 39 & 34 \\
\hline & Grassland & $7.4 \pm 0.3$ & $2.9 \pm 0.2$ & $1.1 \pm 0.1$ & $0.11 \pm 0.01$ & $9.0 \pm 0.6$ & 29 & 37 & 34 \\
\hline \multirow[t]{2}{*}{ WA-O } & Sorghum & $6.7 \pm 0.4$ & $1.7 \pm 0.0$ & $0.5 \pm 0.0$ & $0.07 \pm 0.01$ & $9.3 \pm 1.9$ & 22 & 71 & 8 \\
\hline & Grassland & $7.2 \pm 0$ & $1.8 \pm 0.1$ & $0.6 \pm 0.1$ & $0.07 \pm 0.01$ & $2.4 \pm 0.1$ & 26 & 67 & 8 \\
\hline \multirow[t]{2}{*}{ TX-C } & Sorghum & $8.3 \pm 0.1$ & $2.7 \pm 0.3$ & $2.1 \pm 0.1$ & $0.10 \pm 0.01$ & $14.9 \pm 2.0$ & 15 & 27 & 58 \\
\hline & Grassland & $8.2 \pm 0.0$ & $3.0 \pm 0.3$ & $2.6 \pm 0.3$ & $0.14 \pm 0.01$ & $19.4 \pm 9.5$ & 12 & 24 & 64 \\
\hline \multirow[t]{2}{*}{ WI } & Switchgrass & $6.5 \pm 0.1$ & $4.3 \pm 0.3$ & $2.9 \pm 0.3$ & $0.21 \pm 0.03$ & $25.9 \pm 1.4$ & 9 & 70 & 21 \\
\hline & Grassland & $6.6 \pm 0.4$ & $2.7 \pm 0.7$ & $1.9 \pm 0.8$ & $0.11 \pm 0.04$ & $12.0 \pm 2.4$ & 73 & 18 & 9 \\
\hline \multirow[t]{2}{*}{ WA-P } & Switchgrass & $7.1 \pm 0.1$ & $1.1 \pm 0.1$ & $0.4 \pm 0.0$ & $0.03 \pm 0.01$ & $8.9 \pm 0.9$ & 80 & 16 & 4 \\
\hline & Grassland & $7.4 \pm 0$ & $0.9 \pm 0.0$ & $0.4 \pm 0.0$ & $0.03 \pm 0.00$ & $0.9 \pm 0.1$ & 80 & 16 & 4 \\
\hline \multirow[t]{3}{*}{ IL } & Switchgrass & $5.9 \pm 0.1$ & $4.3 \pm 0.0$ & $2.4 \pm 0.0$ & $0.22 \pm 0.00$ & $20.3 \pm 1.0$ & 9 & 70 & 21 \\
\hline & Grassland & $6.5 \pm 0.1$ & $4.1 \pm 0.2$ & $2.5 \pm 0.1$ & $0.21 \pm 0.01$ & $18.4 \pm 1.4$ & 9 & 70 & 21 \\
\hline & Native Grassland & $7.3 \pm 0.2$ & $7.3 \pm 2.6$ & $5.8 \pm 1.4$ & $0.37 \pm 0.14$ & $27 \pm 6$ & 9 & 65 & 26 \\
\hline \multirow[t]{2}{*}{ SD } & Switchgrass & $7.1 \pm 1.0$ & $3.6 \pm 1.1$ & $2.9 \pm 0.5$ & $0.13 \pm 0.03$ & $18 \pm 7$ & 23 & 50 & 27 \\
\hline & Grassland & $7.6 \pm 0.0$ & $4.8 \pm 0.6$ & $2.9 \pm 0.1$ & $0.24 \pm 0.02$ & $25 \pm 5$ & 23 & 50 & 27 \\
\hline \multirow[t]{2}{*}{$\mathrm{TN}$} & Switchgrass & $6.5 \pm 0.2$ & $2.5 \pm 0.2$ & $1.0 \pm 0.1$ & $0.10 \pm 0.01$ & $22.2 \pm 1.4$ & 11 & 78 & 12 \\
\hline & Grassland & $6.0 \pm 0.1$ & $3.4 \pm 0.3$ & $1.3 \pm 0.1$ & $0.15 \pm 0.01$ & $19.8 \pm 1.8$ & 11 & 70 & 19 \\
\hline \multirow[t]{2}{*}{ NE } & Switchgrass & $6.1 \pm 0.1$ & $3.3 \pm 0.1$ & $1.7 \pm 0.1$ & $0.17 \pm 0.02$ & $23.8 \pm 0.8$ & 9 & 61 & 30 \\
\hline & Grassland $(n=1)$ & 6.1 & 5.1 & 2.9 & 0.24 & 25.5 & 34 & 32 & 34 \\
\hline
\end{tabular}

Sand, silt, and clay content based on USDA Natural Resources Conservation Service data (http://websoilsurvey.nrcs.usda.gov/app/HomePage.htm) 
Table 4 Mean $\pm \mathrm{SE}$ values for soil macronutrients at sampling locations

\begin{tabular}{|c|c|c|c|c|c|c|c|c|}
\hline Location & Land use & $\mathrm{NO}_{3}{ }^{-} \mathrm{N}(\mathrm{ppm})$ & $\mathrm{NH}_{4}{ }^{+}-\mathrm{N}(\mathrm{ppm})$ & Bray-P (ppm) & $\mathrm{K}(\mathrm{ppm})$ & $\mathrm{Ca}(\mathrm{ppm})$ & $\mathrm{Mg}(\mathrm{ppm})$ & $\mathrm{SO}_{4}{ }^{2-}-\mathrm{S}(\mathrm{ppm})$ \\
\hline \multirow[t]{2}{*}{ TX-A } & Sorghum & $63 \pm 49$ & $2.0 \pm 0.3$ & $61 \pm 25$ & $610 \pm 85$ & $3,100 \pm 500$ & $514 \pm 26$ & $15 \pm 8$ \\
\hline & Grassland & $1.8 \pm 1.2$ & $2.2 \pm 0.1$ & $19 \pm 5$ & $430 \pm 21$ & $2,500 \pm 300$ & $496 \pm 51$ & $2.6 \pm 0.4$ \\
\hline \multirow[t]{2}{*}{ WA-O } & Sorghum & $110 \pm 46$ & $26 \pm 6$ & $36 \pm 3$ & $250 \pm 64$ & $1,300 \pm 163$ & $190 \pm 21$ & $38 \pm 30$ \\
\hline & Grassland & $2.3 \pm 0.8$ & $3.7 \pm 0.5$ & $23 \pm 3$ & $300 \pm 44$ & $847 \pm 17$ & $170 \pm 10$ & $1.5 \pm 0.0$ \\
\hline \multirow[t]{2}{*}{ TX-C } & Sorghum & $4.4 \pm 0.3$ & $1.7 \pm 0.3$ & $5 \pm 2$ & $280 \pm 41$ & $5,700 \pm 670$ & $340 \pm 38$ & $6 \pm 3$ \\
\hline & Grassland & $8.6 \pm 2.7$ & $12 \pm 9$ & $6 \pm 3$ & $390 \pm 55$ & $6,000 \pm 810$ & $260 \pm 71$ & $16 \pm 10$ \\
\hline \multirow[t]{2}{*}{ WI } & Switchgrass & $11.4 \pm 2.5$ & $3.6 \pm 1.2$ & $25 \pm 7$ & $150 \pm 42$ & $1,500 \pm 91$ & $430 \pm 32$ & $3.2 \pm 1.0$ \\
\hline & Grassland & $3.3 \pm 2.8$ & $5.6 \pm 2.0$ & $19 \pm 9$ & $70 \pm 14$ & $810 \pm 390$ & $250 \pm 129$ & $2.4 \pm 0.4$ \\
\hline \multirow[t]{2}{*}{ WA-P } & Switchgrass & $1.7 \pm 0.2$ & $2.2 \pm 0.5$ & $33 \pm 3$ & $192 \pm 14$ & $640 \pm 81$ & $111 \pm 5$ & $4.6 \pm 0.6$ \\
\hline & Grassland & $4.3 \pm 0.6$ & $1.4 \pm 0.1$ & $17 \pm 1$ & $202 \pm 2$ & $662 \pm 22$ & $101 \pm 6$ & $2.6 \pm 0.1$ \\
\hline \multirow[t]{3}{*}{ IL } & Switchgrass & $8.1 \pm 1.3$ & $5.8 \pm 0.4$ & $5 \pm 0$ & $102 \pm 10$ & $1,328 \pm 30$ & $384 \pm 20$ & $3.0 \pm 0.1$ \\
\hline & Grassland & $3.2 \pm 0.4$ & $2.4 \pm 0.1$ & $6 \pm 2$ & $82 \pm 6$ & $1,410 \pm 120$ & $410 \pm 53$ & $2.9 \pm 0.4$ \\
\hline & Native grassland & $6.5 \pm 2.6$ & $3.0 \pm 0.2$ & $3 \pm 0$ & $200 \pm 76$ & $2,800 \pm 444$ & $800 \pm 119$ & $6.3 \pm 0.7$ \\
\hline \multirow[t]{2}{*}{$\mathrm{SD}$} & Switchgrass & $4.2 \pm 2.7$ & $2.4 \pm 0.0$ & $34 \pm 17$ & $170 \pm 98$ & $3,800 \pm 1930$ & $370 \pm 17$ & $2.3 \pm 0.6$ \\
\hline & Grassland & $4 \pm 3$ & $2.6 \pm 0.1$ & $5 \pm 2$ & $160 \pm 50$ & $3,700 \pm 780$ & $700 \pm 440$ & 5.1 \\
\hline \multirow[t]{2}{*}{$\mathrm{TN}$} & Switchgrass & $2.7 \pm 0.5$ & $2.3 \pm 0.5$ & $16 \pm 5$ & $84 \pm 16$ & $1,110 \pm 117$ & $77 \pm 4$ & $2.5 \pm 0.1$ \\
\hline & Grassland & $6.3 \pm 1.4$ & $6.4 \pm 0.8$ & $7 \pm 2$ & $99 \pm 16$ & $1,260 \pm 197$ & $200 \pm 50$ & $4.8 \pm 0.9$ \\
\hline \multirow[t]{2}{*}{$\mathrm{NE}$} & Switchgrass & $4.3 \pm 0.3$ & $5.2 \pm 2.9$ & $9 \pm 3$ & $320 \pm 47$ & $2,100 \pm 360$ & $440 \pm 152$ & $2.1 \pm 0.2$ \\
\hline & Grassland $(n=1)$ & 5.4 & 6.3 & 6 & 338 & 1,825 & 478 & 2.5 \\
\hline
\end{tabular}

ethanol was added, and (c) after the ethanol wash steps and the final spin, DNA was eluted in $5 \mathrm{ml}$ sterile nuclease-free PCR grade water. Genomic DNA was dried in a DNA120 SpeedVac Concentrator (Thermo Inc. Asheville, NC) and was resuspended in $200 \mu \mathrm{l}$ Solution C6. DNA concentrations were determined using a NanoDrop ND-1000 Spectrophotometer (Thermo Inc., Waltham MA). The DNA sample concentrations were adjusted to $20 \mathrm{ng} / \mu \mathrm{l}$.

Table 5 Mean \pm SE values for soil micronutrients and sodium at sampling locations

\begin{tabular}{|c|c|c|c|c|c|c|c|}
\hline Location & Land use & $\mathrm{B}(\mathrm{ppm})$ & $\mathrm{Cu}(\mathrm{ppm})$ & $\mathrm{Fe}(\mathrm{ppm})$ & Mn (ppm) & Zn (ppm) & $\mathrm{Na}(\mathrm{ppm})$ \\
\hline \multirow[t]{2}{*}{ TX-A } & Sorghum & $0.5 \pm 0.0$ & $0.6 \pm 0.0$ & $19 \pm 5$ & $12 \pm 3$ & $2.0 \pm 0.6$ & $91 \pm 29$ \\
\hline & Grassland & $0.5 \pm 0.0$ & $0.6 \pm 0.0$ & $24 \pm 5$ & $19 \pm 3$ & $1.4 \pm 0.3$ & $23 \pm 2$ \\
\hline \multirow[t]{2}{*}{ WA-O } & Sorghum & $0.2 \pm 0.0$ & $0.9 \pm 0.1$ & $15 \pm 6$ & $10 \pm 6$ & $2.4 \pm 0.5$ & $18 \pm 2$ \\
\hline & Grassland & $0.3 \pm 0.0$ & $0.7 \pm 0.0$ & $6 \pm 1$ & $3 \pm 0$ & $<0.1$ & $11 \pm 1$ \\
\hline \multirow[t]{2}{*}{ TX-C } & Sorghum & $0.6 \pm 0.1$ & $10.8 \pm 0.8$ & $68 \pm 16$ & $53 \pm 7$ & $<0.1$ & $62 \pm 23$ \\
\hline & Grassland & $1.0 \pm 0.5$ & $12.6 \pm 1.8$ & $100 \pm 43$ & $65 \pm 14$ & $4.4 \pm 4.3$ & $26 \pm 11$ \\
\hline \multirow[t]{2}{*}{ WI } & Switchgrass & $0.3 \pm 0.0$ & $2.7 \pm 0.3$ & $90 \pm 6$ & $26 \pm 4$ & $4.3 \pm 1.2$ & $11 \pm 2$ \\
\hline & Grassland & $0.2 \pm 0.1$ & $2.3 \pm 0.3$ & $43 \pm 7$ & $27 \pm 7$ & $2.7 \pm 0.3$ & $6 \pm 0$ \\
\hline \multirow[t]{2}{*}{ WA-P } & Switchgrass & $0.1 \pm 0.0$ & $0.3 \pm 0.0$ & $22 \pm 2$ & $3 \pm 0$ & $0.7 \pm 0.1$ & $22 \pm 1$ \\
\hline & Grassland & $0.1 \pm 0.0$ & $0.3 \pm 0.0$ & $14 \pm 1$ & $3 \pm 0$ & $0.6 \pm 0.0$ & $15 \pm 0$ \\
\hline \multirow[t]{3}{*}{ IL } & Switchgrass & $0.5 \pm 0.0$ & $3.0 \pm 0.0$ & $131 \pm 5$ & $20 \pm 3$ & $4.0 \pm 0.0$ & $21 \pm 0$ \\
\hline & Grassland & $0.4 \pm 0.1$ & $3.0 \pm 0.0$ & $70 \pm 6$ & $19 \pm 2$ & $3.3 \pm 0.3$ & $22 \pm 1$ \\
\hline & Native grassland & $0.7 \pm 0.2$ & $3.7 \pm 0.3$ & $70 \pm 31$ & $18 \pm 3$ & $31 \pm 28$ & $23 \pm 1$ \\
\hline \multirow[t]{2}{*}{ SD } & Switchgrass & $0.4 \pm 0.1$ & $1.1 \pm 0.3$ & $60 \pm 54$ & $15 \pm 9$ & $4.9 \pm 1.8$ & $39 \pm 0$ \\
\hline & Grassland & $0.7 \pm 0.2$ & $1.1 \pm 0.2$ & $42 \pm 13$ & $15 \pm 6$ & $0.9 \pm 0.8$ & $120 \pm 66$ \\
\hline \multirow[t]{2}{*}{$\mathrm{TN}$} & Switchgrass & $0.1 \pm 0.0$ & $0.5 \pm 0.0$ & $69 \pm 4$ & $42 \pm 9$ & $0.8 \pm 0.0$ & $17 \pm 0$ \\
\hline & Grassland & $0.1 \pm 0.0$ & $0.5 \pm 0.0$ & $120 \pm 35$ & $26 \pm 5$ & $1.2 \pm 0.2$ & $21 \pm 2$ \\
\hline \multirow[t]{2}{*}{$\mathrm{NE}$} & Switchgrass & $0.5 \pm 0.1$ & $0.9 \pm 0.1$ & $53 \pm 14$ & $24 \pm 2$ & $<0.1$ & $30 \pm 1$ \\
\hline & Grassland $(n=1)$ & 0.5 & 0.8 & 57 & 15 & 1.1 & 27 \\
\hline
\end{tabular}


Microarray Analyses with GeoChip 4.0

To measure potential differences in microbial abundance and functional diversity for soil ecosystem services, we utilized GeoChip 4.0, a functional microbial gene array $[17,33]$. GeoChip 4.0 provides a broad representation of probes for genes involved in many microbial processes [23]; it contains over 83,000 probes distributed among 15 categories of functional genes. The GeoChip probes are designed based on sequences available in the GenBank database that are derived from both unculturable and culturable soil microorganisms. The 15 gene categories represented on the GeoChip 4.0 include antibiotic resistance, bacteriophage, carbon cycling, metabolic energy, fungal functions, metal resistance, nitrogen cycling, organic remediation, phosphorus utilization, stress tolerance, sulfur utilization, other genes, soil benefit, soil pathogens, and virulence. The soil benefit category contains microbial genes shown to be beneficial to plant growth by protecting plants from pathogens, enhancing water or nutrient uptake, or stimulating growth; examples of genes in the benefit category include those involved in antibiotic, plant hormone, and siderophore production.

DNA preprocessing, hybridizations to GeoChip 4.0, and microarray data collection were carried out at Glomics Inc., Norman, OK using methods that were similar to those previously described [23]. Briefly, the preprocessing steps for soil genomic DNA samples included amplification of $4 \mu \mathrm{g}$ of whole community genomic DNA, followed by labeling of $2 \mu \mathrm{g}$ of amplified DNA with Cy-3 using random primers and the Klenow fragment of DNA polymerase I [34]. Sample tracking control (NimbleGen, Madison, WI, USA) was added to samples after drying, washing, and rehydration. The hybridization buffer contained Cy5labeled common oligo reference standard (CORS) target and Cy3-labeled alignment oligo (NimbleGen). The CORS probes were placed randomly throughout the GeoChip 4.0 array and were used for signal normalization $[23,35]$. The quality of microarray spots was assessed, and low-quality spots were removed prior to statistical analysis [36]. The spots were scored as positive if the signal-to-noise ratio was $>2.0$ and the coefficient of variability of the background was $<0.8$. Singlet genes (detected in only one sample) were removed [23]. Data used in our analyses of microbial gene functional diversity and abundance were further restricted to those genes that were detected in at least two out of the three replicate sampling sites for individual crop or grassland geographic locations. The number of positive genes within each category (diversity) was normalized to the mean across samples for that category. Mean signal intensity values of microbial genes (relative abundance) were calculated by dividing the total signal intensity per gene category for a sample by the number of positive genes detected within that category for the sample. Signal intensities were transformed to reflect relative gene abundance per gram dry weight soil for each sample.

\section{Statistical Methods}

Univariate and multivariate analyses of variances (ANOVAs) were conducted for the FGA, chemistry, and biological data to test for differences between soil obtained from sorghum fields, switchgrass fields, and from perennial reference grasslands. A log or square root transformation was applied as needed to the soil chemistry and microarray gene variables in order to stabilize their variances prior to ANOVA. Linear discriminant analysis (LDA) was used to classify the plots into mutually exclusive groups for switchgrass crop, switchgrass grassland, sorghum crop, and sorghum grassland based on soil chemistry data. All calculations were performed using JMP 6.0 (SAS Institute, Cary, NC) and SAS GLM procedures (SAS Institute Inc., Cary, NC).

Probability values $<0.05$ were considered statistically significant. Pearson correlations among soil FGA, chemistry, and biological data were used to measure the linear association among these diverse soil indices. Under the assumption of zero correlation, the test statistic, $t=r \sqrt{ }(N-2) / \sqrt{ }\left(1-r^{2}\right)$ where $r=$ Pearson correlation and $N=$ sample size, follows a Student's $t$ distribution with N-2 degrees of freedom. Correlation analysis was performed using an application within the microarray data analyses pipeline at the University of Oklahoma Institute for Environmental Genomics (http://ieg.ou.edu/).

\section{Results}

Edaphic properties, microbial gene diversity and abundance, and active microbial biomass varied by geographic location, crop type, and/or land use, (i.e., crop or reference grassland). In particular, differences between crop and grassland soils varied by location and crop as indicated by significant land use $\times$ location interactions in the ANOVAs. These land use differences in microbial biomass, gene diversity, and abundance reflect the regional differences in soil types and properties between geographic locations and differences in agronomic practices between switchgrass, a perennial biofuel crop, and sorghum, an annual biofuel crop.

\section{Soil Texture, Chemistry, and Biology}

Soil series and texture varied between the geographically diverse locations; however, with the exception of the SE Texas (TX-C) samples, which were clays, the majority of 
the remaining samples were loamy soils (Table 1). Sand content ranged from 9 to $80 \%$. Likewise, soil chemistry varied widely between locations (see Tables 3, 4, and 5). For example, soil $\mathrm{pH}$ values ranged from acidic ( $\mathrm{pH} 5.9$ ) to basic $(\mathrm{pH} 8.3)$, organic matter values ranged from 0.9 to $7.3 \%$, and nitrate from 2 to $114 \mathrm{ppm}$ (Tables 3, 4, and 5).

The LDA of soil chemistry data correctly differentiated $90 \%(47 / 52)$ of the soil samples with regard to whether they were crop or grassland reference soils (Fig. 2). The sorghum crop and grassland sites were clearly different from the switchgrass crop and grassland sites. Further, the sorghum crop and grassland sites were different in soil chemistry, while the switchgrass crop and grassland groups overlapped. The top five soil chemistry factors that separated the sorghum, switchgrass, and grassland sites in the LDA were $\mathrm{pH}, \mathrm{NO}_{3}{ }^{-} \mathrm{N}, \mathrm{K}, \mathrm{Na}$, and $\% \mathrm{C}$.

Two-way ANOVAs were used to separately compare the sorghum crop versus grassland sites and switchgrass crop versus grassland sites. For the sorghum analyses, there was a significant land-use $\times$ geographic location interaction due to grassland differences; i.e., results for the Southeast TX (TXC) site differed from those at the Texas panhandle, (TX-A), and Southeast WA, (WA-O), sites. The TX-A and Southeast WA (WA-O) crop soil samples were significantly higher in $\mathrm{NO}_{3}{ }^{-}-\mathrm{N}(50 \pm 34$ versus $1.4 \pm 0.7 \mathrm{ppm} ; P<0.001), \mathrm{NH}_{4}{ }^{+}-\mathrm{N}$ ( $14 \pm 6$ versus $3.0 \pm 0.4 \mathrm{ppm} ; P=0.007), \mathrm{SO}_{4}{ }^{2-}-\mathrm{S}(13 \pm 9$ versus $2.0 \pm 0.3 \mathrm{ppm} ; P=0.009)$, and $\mathrm{Cu}(0.71 \pm 0.08$ versus $0.61 \pm 0.03 \mathrm{ppm} ; P=0.037)$ than the grassland samples. At all three sets of sorghum sites, Na concentrations were greater in the crop than the grassland soils ( $42 \pm 14$ versus $17 \pm 3 \mathrm{ppm}$; $P=0.005)$. Overall, there were few crop versus grassland differences among switchgrass sites. Soil $\mathrm{pH}$ tended to be higher in the grassland sites (TN excluded; $7.0 \pm 0.1$ versus $6.5 \pm 0.2 ; P=0.062)$, while Fe was significantly higher in the crop sites ( $73 \pm 13$ versus $49 \pm 8$ ppm; $P=0.035$ ).

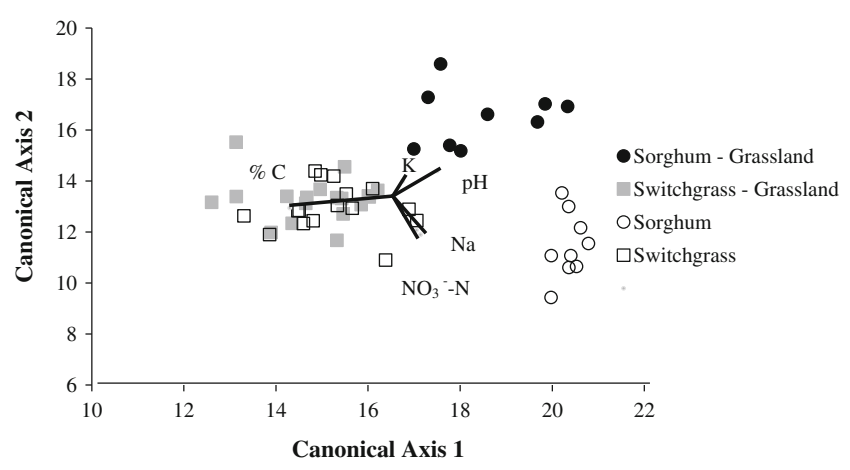

Fig. 2 Linear discriminant analysis of sorghum and switchgrass crop and grassland soil samples. Biplot rays are shown for the five most important soil chemistry variables used to create the discriminant function. The relative influence of the five variables in descending order was $\mathrm{pH}>\mathrm{NO}_{3}{ }^{-}-\mathrm{N}>\mathrm{K}>\mathrm{Na}>\% \mathrm{C}$. Larger differences were observed between sorghum crop and grassland soils than between switchgrass crop and grassland soils
Both switchgrass crop and grassland sites had significantly higher active bacterial biomass content than the sorghum sites ( $25.3 \pm 1.9$ versus $15.6 \pm 1.2 \mu \mathrm{g} / \mathrm{g}$ dry wt.; $P=0.001)$, while no significant differences were observed for active fungal biomass ( $5.0 \pm 1.0$ versus $4.8 \pm 1.4 \mu \mathrm{g} / \mathrm{g}$ dry wt.; $P=0.926)$. Within the sorghum locations, crop and grassland sites did not differ significantly in terms of active bacterial biomass ( $15.1 \pm 1.8$ versus $16.0 \pm 1.8 \mu \mathrm{g} / \mathrm{g}$ dry wt.; $P=0.727$ ) or active fungal biomass $(4.1 \pm 1.7$ versus $5.5 \pm 2.4 \mu \mathrm{g} / \mathrm{g}$ dry wt.; $P=0.622$ ). Likewise, the switchgrass crop and grassland sites did not differ significantly in active bacterial biomass (24.8 \pm 2.3 versus $25.8 \pm 3.1 \mu \mathrm{g} / \mathrm{g}$ dry wt.; $P=0.253$ ). However, four of the six switchgrass locations (IL, SD, WA-P, and WI) tended to have higher levels of active fungal biomass in the crop sites as compared to grassland sites $(P=0.068)$.

\section{FGA Data}

We were able to collect GeoChip 4.0 FGA data that passed the signal to noise ratio criteria from 38,016 probes across all 15 gene categories with our samples. That represented $45 \%$ of the total number of probes present on the microarray chips. The mean number of probes for which data were collected in all replicate sampling sites from individual crop and grassland sampling locations was $16,889 \pm 464$ (SE). The mean number of probes by functional gene category detected in the soil community DNA samples were as follows: antibiotic resistance, $576 \pm 15$; bacteriophage, $84 \pm$ 2; carbon cycling, 2,018 \pm 56 ; metabolic energy, $167 \pm 5$; fungal functions, $659 \pm 20$; metal resistance, $1,885 \pm 51$; nitrogen cycling, $1,135 \pm 34$; organic remediation, $4,065 \pm 125$; phosphorus utilization, $241 \pm 6$; stress tolerance, $3,399 \pm 91$; sulfur utilization, $482 \pm 16$; other genes, $305 \pm 9$; soil benefit, $700 \pm 18$; soil pathogens, $211 \pm 6$; and virulence, $556 \pm 12$. Preliminary analyses of the data down to the level of the gene name (for example gene category: nitrogen cycling; gene subcategory: denitrification; gene name nirS) indicated that the dominant patterns of difference among the samples were captured at the gene category tier (results not shown). Thereafter, further testing for changes affecting individual genes was not included for this study.

ANOVA results for the FGA data from switchgrass locations showed statistically significant interactions $(P \leq 0.05)$ between geographic location and land use (crop or grassland). For example, upon inspection of the relative gene abundance sample means, an interaction was observed that was largely due to grassland versus crop differences for the TN samples, as compared to the other five regional switchgrass locations.

When data for sorghum and switchgrass locations were combined (Table 6), the number of positive genes detected among geographic locations, land use, and their interactions were each statistically significant $(P<0.05)$ across the 


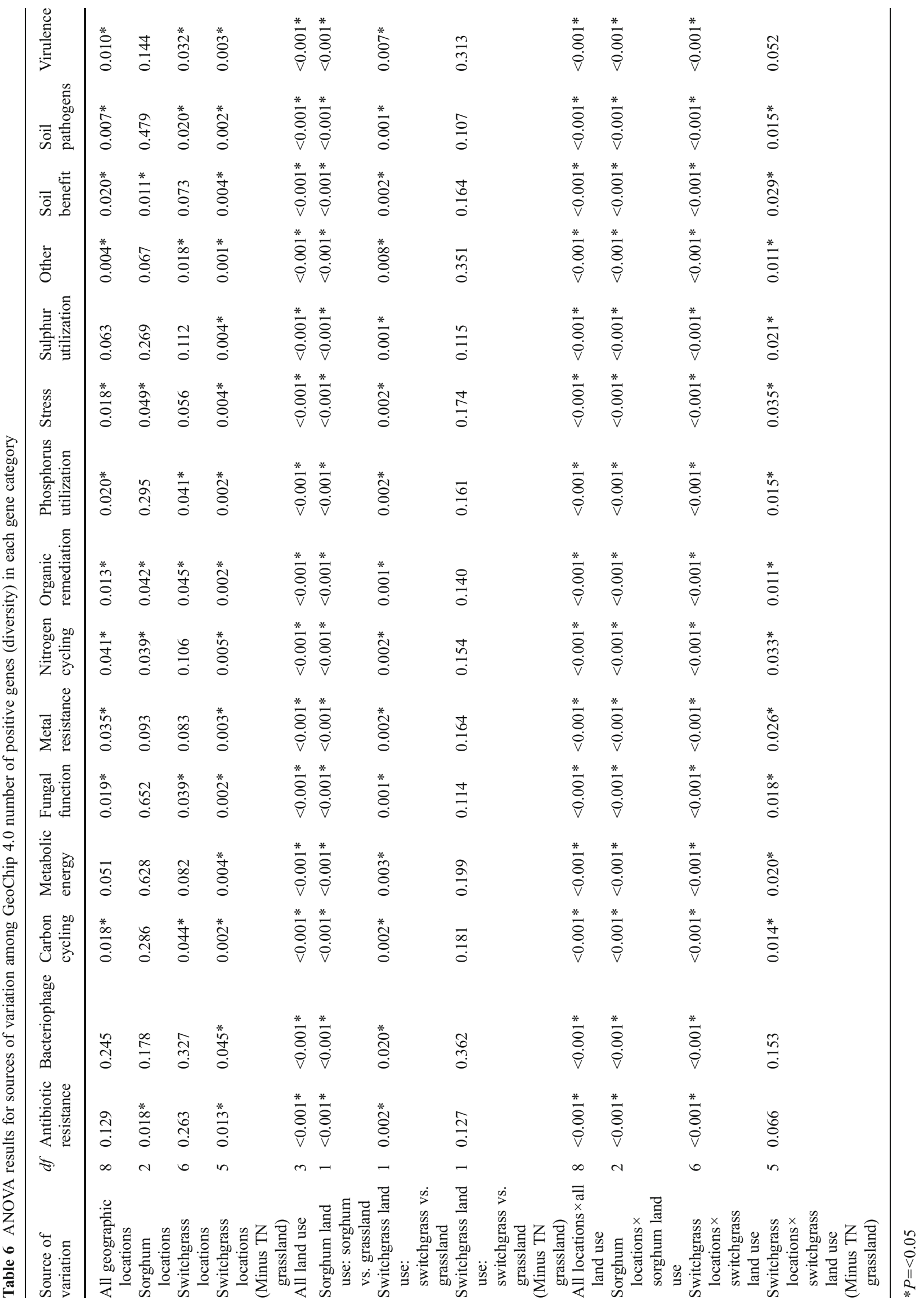


majority of 15 gene categories. For sorghum soils, microbial gene diversity was significantly affected by land use, but differences between crop and grassland sites varied by geographic location as indicated by a statistically significant interaction across all 15 GeoChip 4.0 gene categories. The normalized number of positive carbon cycling, nitrogen cycling, phosphorus utilization, and sulphur utilization genes are shown in Fig. 3. Crop versus grassland comparisons within four FGA gene categories $(\mathrm{C}, \mathrm{N}, \mathrm{P}$, and $\mathrm{S})$ were generally representative of the patterns seen across all gene categories for each sample location. Sorghum soils had consistently lower microbial gene diversity than grassland samples in the four gene categories (Fig. 3a). The difference was significant for all sorghum location $\times$ land use combinations except for sulphur utilization at the Eastern TX (TX$\mathrm{Cc}$ and TX-Cn) sites.
For switchgrass soil samples, geographic location was a significant source of variation of microbial gene diversity (Table 6). This was true in seven GeoChip 4.0 gene categories. There were statistically significant interactions between geographic location and land use for all 15 gene categories for switchgrass. The switchgrass and grassland soil microbial gene diversity patterns were very similar across gene categories, but they were inconsistent among the sampling locations (Fig. 3b). At the WA-P and TN locations, we observed significantly lower gene diversity in switchgrass fields than in nearby grassland soils in all 15 gene categories. At the WA-P locations, the difference may be attributed to extensive recent deep land grading several years prior to planting of the switchgrass, which had removed much of the topsoil. The lower gene diversity at the TN locations may be explained by the greater disturbance of the sites due to land

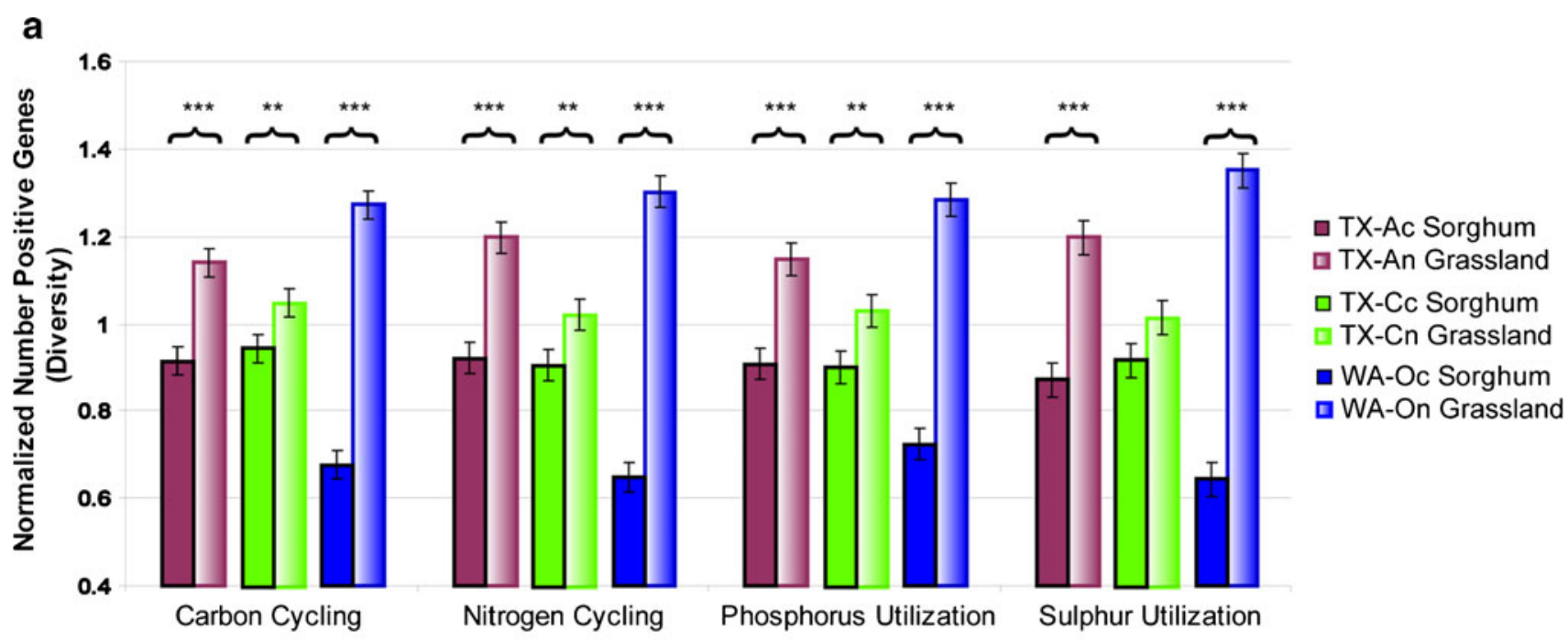

b

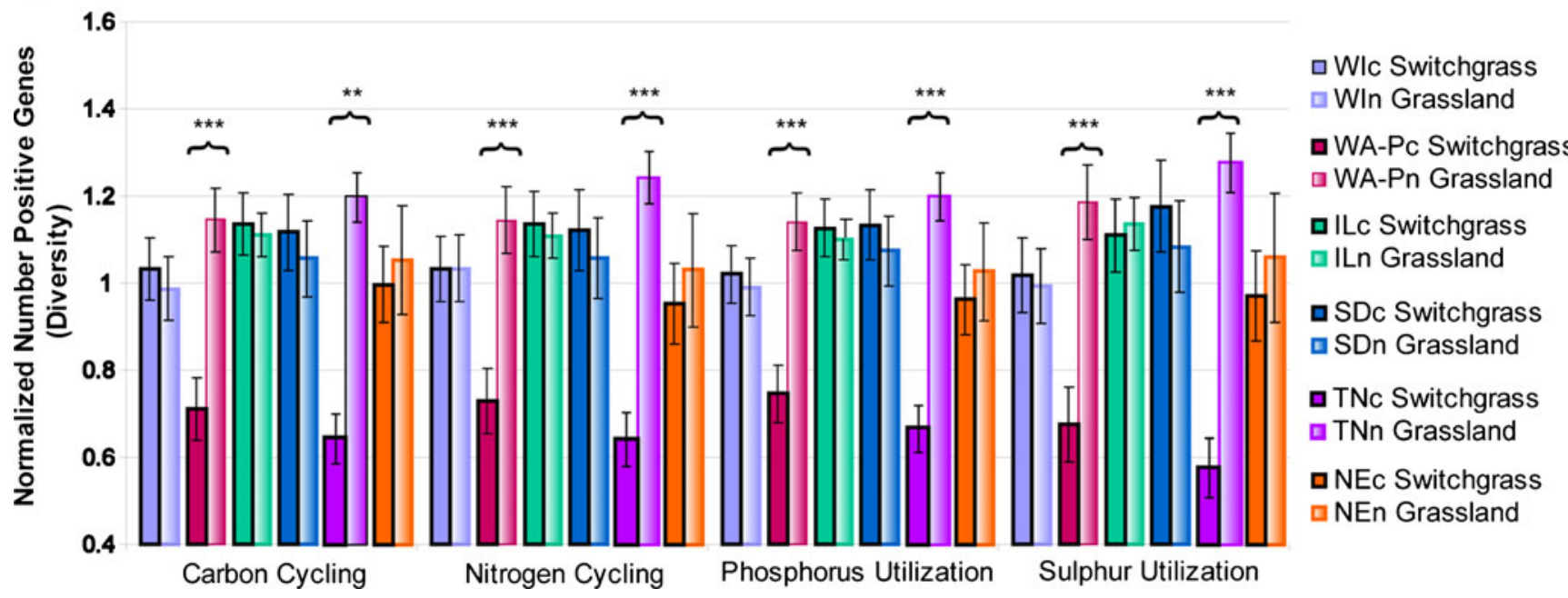

Fig. 3 Normalized number of microbial genes (diversity) in four representative functional gene categories found in a sorghum versus grassland samples and $\mathbf{b}$ in switchgrass and grassland samples.
Significance based on the least squares means test is shown above bracketed pairs of crop and grassland bars for the given geographic locations; ${ }^{* *} \mathrm{P} \leq 0.05$ but $>0.01 ; * * * \mathrm{P} \leq 0.01$ 
clearing of oak-hickory forests in the nineteenth century and to grazing of the long-term pastures for over 40 years. The remainder of our reference sites historically had been perennial grasslands, i.e., tall or short grass prairie or sagebrush steppe.

ANOVA results (Table 7) illustrate the sources of variation in the GeoChip 4.0 signal intensity data which we used to measure relative abundance of microbial genes per gram of dry soil. Differences in signal intensity data between geographic locations were statistically significant across all 15 GeoChip 4.0 gene categories when data for sorghum and switchgrass locations were combined. Crop versus grassland differences were statistically significant across 10 of 15 gene categories at the 0.05 level of significance. For sorghum soil samples, microbial gene abundances from different locations and from crop and grassland areas at the same geographic location were not statistically different. However, there was a trend of lower gene abundance in sorghum soils than grassland samples (Fig. 4a). Variation in gene abundance at switchgrass sites was dependent on geographic location and land use type in all FGA microbial gene categories. Significant interactions between switchgrass locations and land use were detected in all GeoChip 4.0 gene categories. Most switchgrass location $\times$ land use combinations also had lower microbial gene abundance in crop soil than the grassland samples. This difference was statistically significant for the SD crop and grassland soils (Fig. 4b); the exception to this pattern was the TN location, where there was greater relative abundance of microbial genes in the crop soils, as compared to grassland (pasture) samples. Overall, the range of microbial gene abundance variation was less for sorghum sites than switchgrass sites.

\section{Correlations Among Soil FGA, Chemistry, and Biological Data}

Pearson correlation tests were run to see if FGA gene diversity and abundance across sorghum and switchgrass locations were significantly related to soil chemistry and biological data from those sites (see Table 8 Pearson correlation analyses). Gene diversity in at least four FGA categories at sorghum locations was negatively correlated with $\mathrm{NO}_{3}{ }^{-}-\mathrm{N}, \mathrm{NH}_{4}{ }^{+}-\mathrm{N}$, and $\mathrm{SO}_{4}{ }^{2-}-\mathrm{S}$. In contrast, gene diversity across six or more gene categories at switchgrass locations was positively correlated with $\mathrm{NO}_{3}{ }^{-}-\mathrm{N}$, percent organic matter, and percent clay. Switchgrass gene diversity was negatively correlated to Bray-P. Interestingly, the relative microbial gene abundance at sorghum locations was positively correlated to percent sand. Gene abundance at switchgrass sites was positively correlated to $\mathrm{Mn}$.

\section{Discussion}

Our data support the hypotheses that (1) soils from perennial switchgrass fields would be more similar to nearby grassland soils than soils from sorghum fields and (2) that trend would be observed in multiple geographies and different soils. For example, the levels of N, K, S, Na, and $\mathrm{Ca}$ as well as $\mathrm{pH}$ differed more between sorghum crop and grassland samples than between switchgrass crop soils and their nearby grassland sites. Our active microbial biomass data indicated that switchgrass soils were much more similar to grassland soils than were sorghum soils. Using the GeoChip FGA approach, we observed that microbial gene diversity was significantly lower in sorghum soils than nearby grassland soils. Microbial gene abundance did not differ between sorghum crop and grassland soils, but was generally lower in switchgrass soils as compared to nearby grassland soils.

The differences we observed in soil chemistry and microbial communities are likely linked to differences in land use, agronomic practices, and soil type [37-42]. Higher macronutrient levels in the sorghum sites than nearby grassland sites are likely the result of fertilizer additions during cultivation. These additions may have decreased the microbial gene diversity within the sorghum crop fields as the significant differences in gene diversity in neighboring sorghum crop and grassland soils were negatively correlated with concentrations of $\mathrm{NO}_{3}{ }^{-}-\mathrm{N}, \mathrm{NH}_{4}{ }^{+}-\mathrm{N}$, and $\mathrm{SO}_{4}{ }^{2-}-\mathrm{S}$. Allelochemicals released by sorghum roots into the soil and release of cyanide-containing compounds from leaves after frost may also have negatively impacted the diversity of plant-associated soil microbial communities in the sorghum fields [43-45].

The GeoChip data suggest that while sorghum agronomic practices decreased gene diversity compared to nearby grasslands, the overall gene abundance was not affected. In contrast, genetic diversity was similar between switchgrass fields and grasslands, while the abundance of the microbial genes was lower than in nearby grassland soils. These subtle but important differences present opportunities for future studies. They also suggest that the higher gene diversity in switchgrass (and perhaps other perennial) soils may foster higher sustainability of ecosystem services and greater resilience of plant-associated microbes and plants to environmental stressors.

Use of the GeoChip 4.0 additionally permitted exploration of the microbial community impacts of the differences in soil chemistry and structure within and across multiple gene categories that related to important ecosystem processes such as C, N, P, and S cycling. For instance, we observed some significant differences among the $\mathrm{N}$-cycling genes for the sorghum crop and grassland sites for nitrogen fixation, nitrification, and denitrification. Interestingly, effects of $\mathrm{N}$ fertilization have been reported to impact the number of 


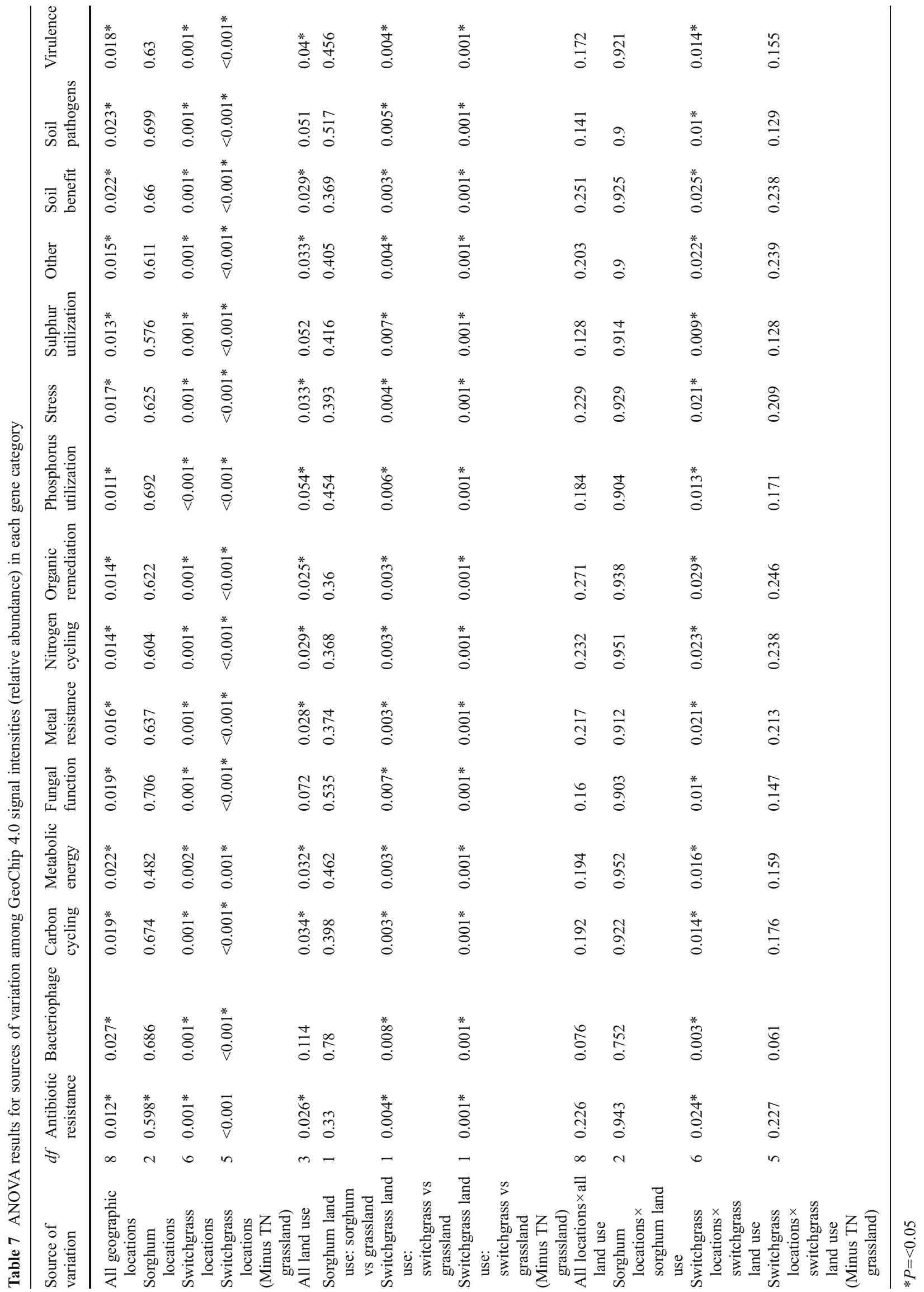


a

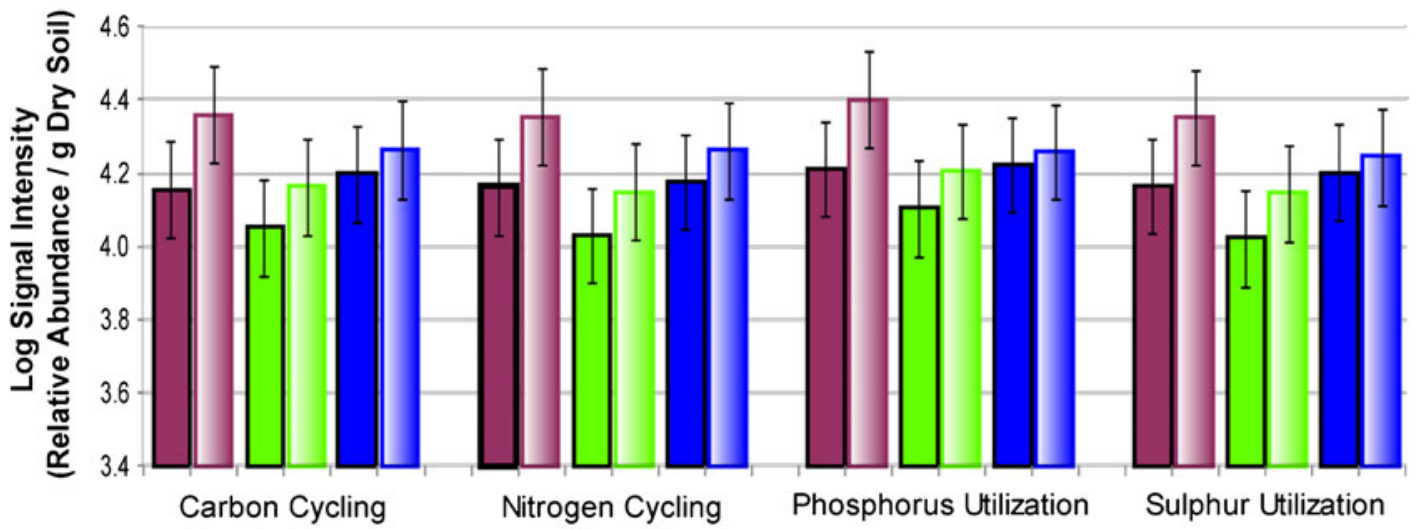

口TX-Ac Sorghum 口TX-An Grassland

口TX-Cc Sorghum - TX-Cn Grassland

-WA-Oc Sorghum WW-On Grassland

b

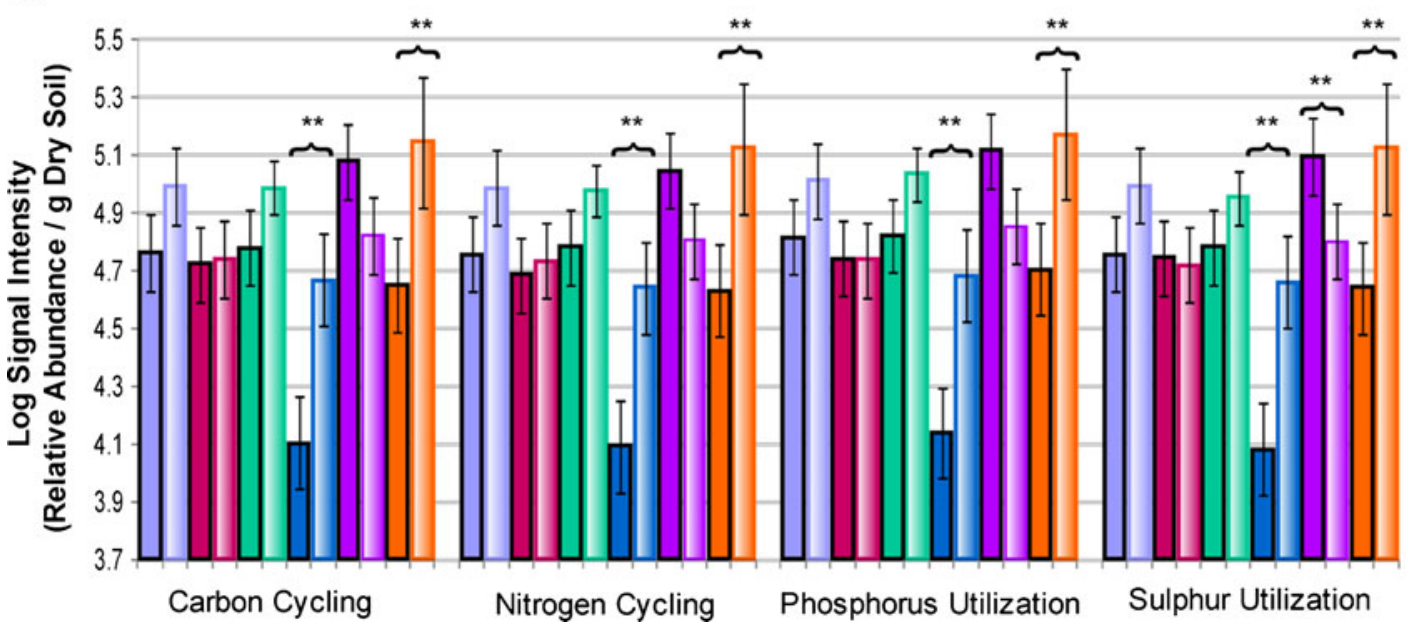

口Wlc Switchgrass 口WIn Grassland

口WA-Pc Switchgrass -WA-Pn Grassland

口ILc Switchgrass - ILn Grassland

口SDc Switchgrass 口SDn Grassland

口TNc Switchgrass -TNn Grassland

口NEc Switchgrass aNEn Grassland

Fig. 4 Log signal intensity (relative gene abundance per gram of dry soil) of microbial genes in four representative functional categories found in a sorghum versus grassland samples and $\mathbf{b}$ in switchgrass and

copies of nifH genes in the rhizosphere of sorghum [46], numbers of ammonia-oxidizing bacteria denitrifiers [47], numbers of plant growth-promoting rhizobacteria in sorghum soils [48], and abundance of ammonia oxidizers and denitrifiers in maize soils [49]. The lower microbial gene diversity in sorghum soil samples was not restricted to genes within the carbon cycling, nitrogen cycling, phosphorus utilization, and sulphur utilization. Rather, it extended across multiple functional gene categories detected by the GeoChip 4.0. The fact that we did not observe significant differences in abundance or diversity for specific types of $\mathrm{N}$ or $\mathrm{C}$ cycling functional genes was surprising since one might have anticipated finding lower abundance or diversity of, e.g., nitrogenase or ammonia oxidase genes under higher levels of $\mathrm{N}$ fertilization, as in sorghum fields. However, quality control checks on the FGA chips and tests of quality and quantity of DNA in our soil samples did not reveal any technical problems. This suggests that any differences among our samples for individual genes were very minor. grassland samples. Significance based on the least squares means test is shown above bracketed pairs of crop and grassland bars for the given geographic locations; $* * \mathrm{P} \leq 0.05$ but $>0.01$

Quantitative real-time PCR targeting specific functional genes could confirm these results, but this was beyond the scope of the current research. Use of additional, complementary molecular analytical methods may improve the limits of detection and maximize the information that can be derived from soil DNA samples.

\section{Ecological Implications}

We are not aware of other studies having looked at as broad a geographic comparison of crop and nearby reference grasslands, i.e., natural, minimally managed perennial grasslands, as we have presented here. For example, regional studies in Kansas and Wisconsin [50, 51] that compared various crops and much more intensively managed grasslands have reported shifts in microbial community composition that may occur with cultivation. In a Michigan study, da C. Jesus et al. [22] reported that soil attributes (principally $\mathrm{pH}$, organic matter, and nutrients) had greater effects 


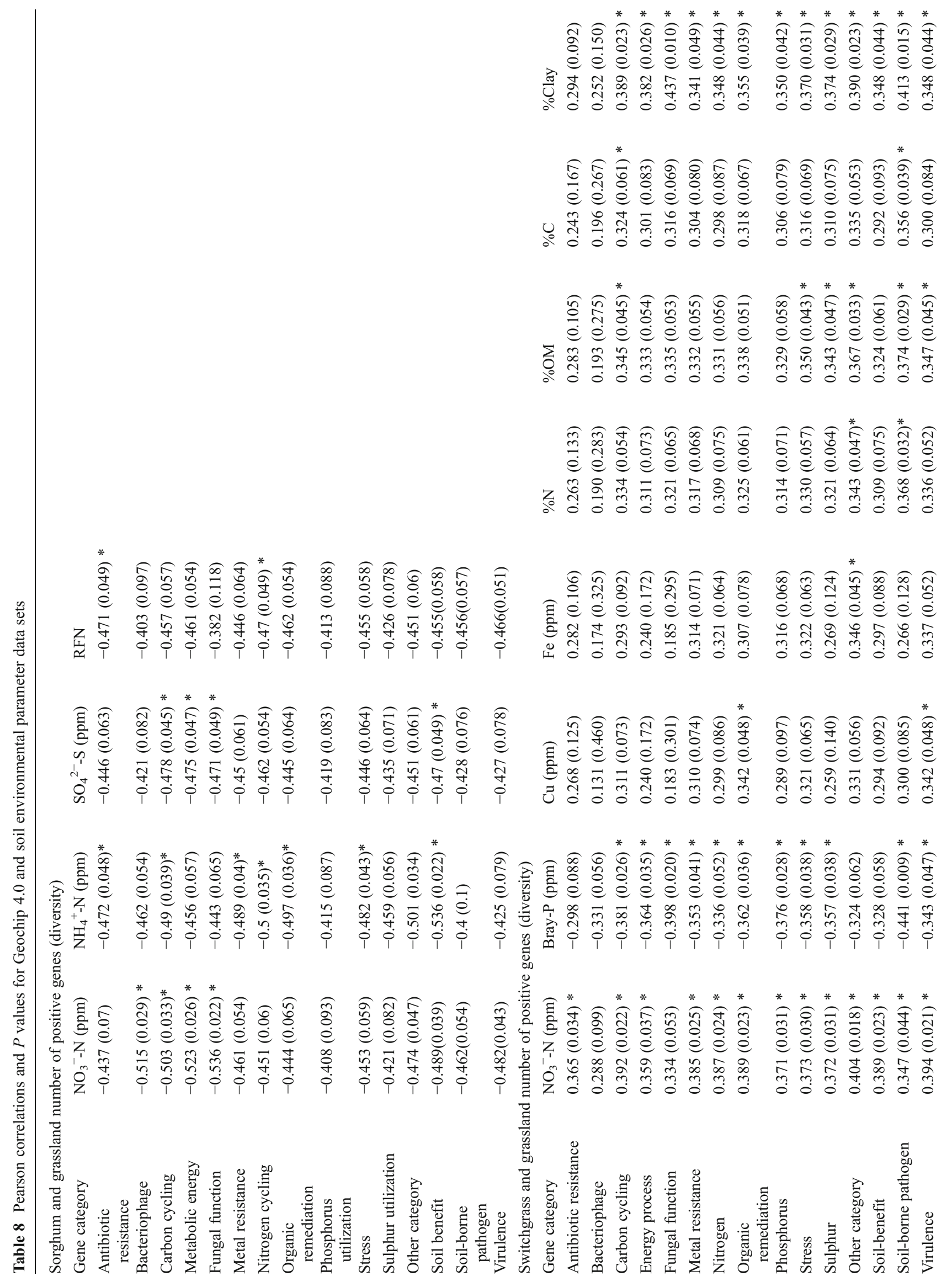




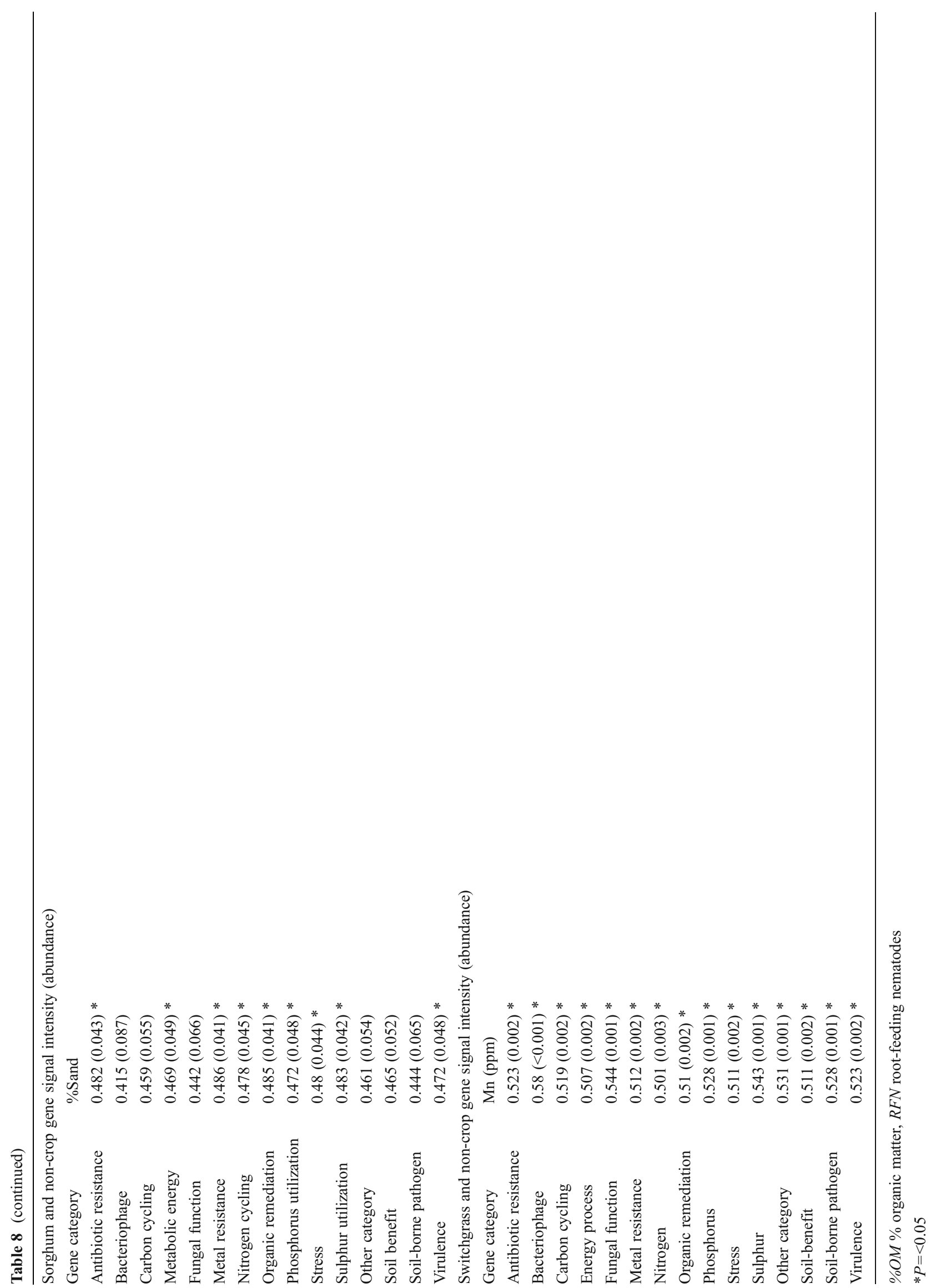


on the diversity of bacterial rhizosphere communities than plant genus when analyzing samples from soybean, canola, sunflower, corn, and switchgrass. The authors noted higher bacterial diversity in the biofuel crop fields than in adjacent forest soils. The da C. Jesus et al. [22] results differ from our sorghum soil microbial diversity results, perhaps because of differences between the methods and designs of our studies. For example, except for the TN pasture sites that had been established on cleared oak-hickory forest land, our biofuel crop sites were paired with nearby perennial grasslands. Additionally, our soil samples were essentially bulk soil, rather than rhizosphere soil samples. Further, while the GeoChip 4.0 FGA we used includes bacterial probes, it additionally has oligonucleotide probes designed from archaea and fungi, two categories not evaluated in the da Jesus et al. [22] studies.

Overall, our molecular data support our hypothesis that switchgrass soils were much more similar to grassland soils than were sorghum soils. Using the GeoChip FGA approach, which is based on DNA probes for functional microbial genes rather than for specific taxa, we observed some significant differences among the $\mathrm{N}$ cycling genes for nitrogen fixation, nitrification, and denitrification. In addition to the known effects of $\mathrm{N}$ fertilization on soil microbial communities [46-49], other factors reported to influence microbial composition and activities in soils include plant species and genotype, soil type, soil structure and $\mathrm{pH}$, and the interactions and feedback between plants and soils [37-42]. Use of the GeoChip 4.0 allowed us to look for microbial gene diversity and abundance differences among diverse geographic samples across multiple gene categories that related to important ecosystem processes such as $\mathrm{C}, \mathrm{N}, \mathrm{P}$, and $\mathrm{S}$ cycling. When the microbial gene diversity of all samples was considered, sorghum samples were parsed by land use that also interacted significantly with geographic location. That is, microbial gene diversity in sorghum soil samples was lower than that in grassland soils, and there was lower microbial gene diversity in sorghum soils compared to grasslands. Our FGA results indicate that the most significant differences were at the microbial community level, rather than at the level of individual types of functional genes.

The very different centers of origin of the two biofuel crops may have impacted our findings of greater microbial gene diversity and abundance in switchgrass as compared to sorghum. That is, sorghum is not native to the USA; it originated in northeastern Africa, whereas switchgrass is a native plant found in the Great Plains, Upper Midwest and Eastern USA, but not in the Far West (WA, OR, and CA). Switchgrass has thus conceivably had a longer period of time to develop a more abundant and diverse indigenous rhizosphere and soil microflora than has sorghum, in areas of the USA where switchgrass is a native species. The soil microbial functional gene diversity data support our hypotheses and are consistent with switchgrass, but not sorghum, being native to much of the USA. In samples from South Dakota, Wisconsin, Illinois, and Nebraska, gene diversity in the perennial switchgrass crop fields was similar to that in reference grasslands. In contrast, functional gene diversity was significantly lower in Washington and Tennessee switchgrass fields as compared to their respective reference grasslands. However, switchgrass is not indigenous to Washington, and although Tennessee is considered within the native range for switchgrass, it was introduced into previously cleared oak-hickory forest land. At all locations, soil gene diversity was lower in the annual crop sorghum fields than in reference grasslands.

While crop sorghum is not considered weedy, it hybridizes with its perennial relative, johnsongrass (Sorghum halepense L.), a noxious weed [52-54]. Thus gene flow from sorghum to johnsongrass, of genes selected or introduced for more rapid growth and abiotic or biotic stress tolerance, could conceivably result in more competitive, harder to control, johnsongrass. It is of interest to note that invasiveness of the noxious exotic weed Centaurea maculosa L. [55, 56] has been attributed in part to the lack of antagonistic or pathogenic soil microbiota that essentially act as biocontrol agents. Our observations of higher microbial gene diversity in switchgrass sites as compared to sorghum sites may thus suggest a lower potential for weediness of either feral cultivated switchgrass or crop-native switchgrass hybrids.

\section{Conclusions}

To help inform crop and land management decisions to ensure the sustainability of both biofuel crop production and soil ecosystem services, we used multidisciplinary analytical methods to compare soils obtained from switchgrass and sorghum crop fields from nine diverse geographic locations in seven states and compared them to nearby perennial grassland reference soils. Despite the large spatial variability in edaphic properties and the wide range of latitudes where soils were sampled, our results suggest that cultivation of switchgrass, a perennial, has less impact on edaphic properties and microbially mediated soil ecosystem services than sorghum, an annual crop. In future studies, it would be of interest to evaluate these and additional biofuel crops in multiple geographic growing areas where the crop soils can be compared longer term to common reference grassland and also to agronomic control sites, by the use of complementary chemical, biological, and molecular methods. 
Acknowledgments The authors thank their respective staff who participated in providing soil samples, photographs, GPS coordinates, and other background information for each of the crop and non-crop sampling locations. This research was funded in part by a United States Environmental Protection Agency (USEPA) Office of Research and Development National Health and Environmental Effects Research Laboratory intramural competitive award to LSW and RJF and by EPA contracts to Dynamac Corporation (EP-D-06-013 and EP-D-11-027). Mention of trade names or commercial products does not imply endorsement for use. The views of the authors do not necessarily reflect those of the Agency. This manuscript has undergone administrative and technical reviews to receive Agency approval for submission for publication in a peer-reviewed scientific journal.

\section{References}

1. Ragauskas AJ, Williams CK, Davison BH, Britovsek G, Cairney J, Eckert CA et al (2006) The path forward for biofuels and biomaterials. Sci 311(5760):484-489. doi:10.1126/science.1114736

2. Fargione J, Hill J, Tilman D, Polasky S, Hawthorne P (2008) Land clearing and the biofuel carbon debt. Sci 319(5867):1235-1238. doi:10.1126/science. 1152747

3. Carroll A, Somerville C (2009) Cellulosic biofuels. Annual Rev Plant Biology 60(1):165-182. doi:10.1146/annurev.arplant.043008.092125

4. Davis SC, Anderson-Teixeira KJ, DeLucia EH (2009) Life-cycle analysis and the ecology of biofuels. Trends Plant Sci 14(3):140 146

5. Tilman D, Socolow R, Foley JA, Hill J, Larson E, Lynd L et al (2009) Beneficial biofuels - the food, energy, and environment trilemma. Sci 325(5938):270-271. doi:10.1126/science.1177970

6. Moon HS, Abercrombie JM, Kausch AP, Stewart CN Jr (2010) Sustainable use of biotechnology for bioenergy feedstocks. Environ Manag 46(4):531-538. doi:10.1007/s00267-010-9503-5

7. Hill J, Nelson E, Tilman D, Polasky S, Tiffany D (2006) Environmental, economic, and energetic costs and benefits of biodiesel and ethanol biofuels. PNAS 103(30):11206-11210. doi:10.1073/ pnas. 0604600103

8. Tilman D, Wedin D, Knops J (1996) Productivity and sustainability influenced by biodiversity in grassland ecosystems. Nat 379 (6567):718-720

9. Hooper DU, Vitousek PM (1997) The effects of plant composition and diversity on ecosystem processes. Sci 277(5330):1302-1305

10. Tilman D, Hill J, Lehman C (2006) Carbon-negative biofuels from low-input high-diversity grassland biomass. Sci 314(5805):15981600. doi:10.1126/science.1133306

11. Dale VH, Kline KL, Wiens J, Fargione J (2010) Biofuels: implications for land use and biodiversity. Ecological Society of America, Washington, DC

12. Maestre FT, Quero JL, Gotelli NJ, Escudero A, Ochoa V, DelgadoBaquerizo $\mathrm{M}$ et al (2012) Plant species richness and ecosystem multifunctionality in global drylands. Sci 335(6065):214-218. doi:10.1126/science. 1215442

13. Midgley GF (2012) Biodiversity and ecosystem function. Sci 335 (6065):174-175. doi:10.1126/science.1217245

14. Tilman D, Knops J, Wedin D, Reich P, Ritchie M, Siemann E (1997) The influence of functional diversity and composition on ecosystem processes. Sci 277(5330):1300-1302. doi:10.1126/ science. 277.5330 .1300

15. Dobranic JK, Zak JC (1999) A microtiter plate procedure for evaluating fungal functional diversity. Mycologia 91(5):756-765

16. Bossio DA, Girvan MS, Verchot L, Bullimore J, Borelli T, Albrecht A et al (2005) Soil microbial community response to land use change in an agricultural landscape of western Kenya. Microb Ecol 49(1):50-62. doi:10.1007/s00248-003-0209-6
17. He Z, Gentry TJ, Schadt CW, Wu L, Liebich J, Chong SC et al (2007) GeoChip: a comprehensive microarray for investigating biogeochemical, ecological and environmental processes. ISME J 1(1):67-77, http://www.nature.com/ismej/journal/v1/n1/suppinfo/ ismej20072s1.html

18. Yergeau E, Kang S, He Z, Zhou J, Kowalchuk GA (2007) Functional microarray analysis of nitrogen and carbon cycling genes across an Antarctic latitudinal transect. ISME J 1(2):163179, http://www.nature.com/ismej/journal/v1/n2/suppinfo/ ismej200724s1.html

19. Zhang Y, Zhang X, Liu X, Xiao Y, Qu L, Wu L et al (2007) Microarray-based analysis of changes in diversity of microbial genes involved in organic carbon decomposition following land use/cover changes. FEMS Microbiol Lett 266(2):144-151. doi:10.1111/j.1574-6968.2006.00511.x

20. Zhou J, Kang S, Schadt CW, Garten CT Jr (2008) Spatial scaling of functional gene diversity across various microbial taxa. PNAS 105(22):7768-7773. doi:10.1073/pnas.0709016105

21. Berthrong ST, Schadt CW, Piñeiro G, Jackson RB (2009) Afforestation alters the composition of functional genes in soil and biogeochemical processes in South American grasslands. Appl Environ Microbiol 75(19):6240-6248. doi:10.1128/aem.01126-09

22. Da C Jesus E, Susilawati E, Smith S, Wang Q, Chai B, Farris R et al (2010) Bacterial communities in the rhizosphere of biofuel crops grown on marginal lands as evaluated by $16 \mathrm{~S}$ rRNA gene pyrosequences. BioEnergy Res 3(1):20-27

23. Lu Z, Deng Y, Van Nostrand JD, He Z, Voordeckers J, Zhou A et al (2012) Microbial gene functions enriched in the Deepwater Horizon deep-sea oil plume. ISME J 6(2):451-460, http://www.nature.com/ ismej/journal/vaop/ncurrent/suppinfo/ismej201191s1.html

24. DeSantis T, Brodie E, Moberg J, Zubieta I, Piceno Y, Andersen G (2007) High-density universal 16S rRNA Microarray analysis reveals broader diversity than typical clone library when sampling the environment. Microb Ecol 53(3):371-383. doi:10.1007/ s00248-006-9134-9

25. Cole JR, Chai B, Farris RJ, Wang Q, Kulam SA, McGarrell DM et al (2005) The Ribosomal Database Project (RDP-II): sequences and tools for high-throughput rRNA analysis. Nucleic Acids Res 33(suppl 1):D294-D296. doi:10.1093/nar/gki038

26. Cole JR, Wang Q, Cardenas E, Fish J, Chai B, Farris RJ et al (2009) The ribosomal database project: improved alignments and new tools for rRNA analysis. Nucleic Acids Res 37(suppl 1): D141-D145. doi:10.1093/nar/gkn879

27. McGrath KC, Mondav R, Sintrajaya R, Slattery B, Schmidt S, Schenk PM (2010) Development of an environmental functional gene microarray for soil microbial communities. Appl Environ Microbiol 76(21):7161-7170. doi:10.1128/aem.03108-09

28. Horneck DA, Hart JM, Topper K, Koepsell B (1989) Methods of soil analysis used in the Soil Testing Laboratory at Oregon State University. Agricultural Experiment Station, Oregon State University, Corvallis

29. Ingham ER, Klein DA (1984) Soil fungi: relationships between hyphal activity and staining with fluorescein diacetate. Soil Biol Biochem 16(3):273-278. doi:10.1016/0038-0717(84)90014-2

30. Schnürer J, Rosswall T (1982) Fluorescein diacetate hydrolysis as a measure of total microbial activity in soil and litter. Appl Environ Microbiol 43(6):1256-1261

31. Van Veen JA, Ladd JN, Frissel MJ (1984) Modelling C and N turnover through the microbial biomass in soil. Plant Soil 76 (1):257-274. doi:10.1007/bf02205585

32. Hazen TC, Dubinsky EA, DeSantis TZ, Andersen GL, Piceno YM, Singh N et al (2010) Deep-sea oil plume enriches indigenous oildegrading bacteria. Sci 330(6001):204-208. doi:10.1126/ science.1195979

33. He Z, Deng Y, Van Nostrand JD, Tu Q, Xu M, Hemme CL et al (2010) GeoChip 3.0 as a high-throughput tool for analyzing 
microbial community composition, structure and functional activity. ISME J 4(9):1167-1179, http://www.nature.com/ismej/journal/ v4/n9/suppinfo/ismej201046s1.html

34. Wu L, Liu X, Schadt CW, Zhou J (2006) Microarray-based analysis of subnanogram quantities of microbial community DNAs by using whole-community genome amplification. Appl Environ Microbiol 72(7):4931-4941. doi:10.1128/aem.02738-05

35. Liang Y, He Z, Wu L, Deng Y, Li G, Zhou J (2010) Development of a common oligonucleotide reference standard for microarray data normalization and comparison across different microbial communities. Appl Environ Microbiol 76(4):1088-1094. doi:10.1128/aem.02749-09

36. He Z, Xu M, Deng Y, Kang S, Kellogg L, Wu L et al (2010) Metagenomic analysis reveals a marked divergence in the structure of belowground microbial communities at elevated CO2. Ecol Lett 13(5):564-575. doi:10.1111/j.1461-0248.2010.01453.x

37. Girvan MS, Bullimore J, Pretty JN, Osborn AM, Ball AS (2003) Soil type is the primary determinant of the composition of the total and active bacterial communities in arable soils. Appl Environ Microbiol 69(3):1800-1809. doi:10.1128/aem.69.3.1800-1809.2003

38. Bezemer TM, Lawson CS, Hedlund K, Edwards AR, Brook AJ, Igual JM et al (2006) Plant species and functional group effects on abiotic and microbial soil properties and plant-soil feedback responses in two grasslands. J Ecol 94(5):893-904. doi:10.1111/ j.1365-2745.2006.01158.x

39. Pereira e Silva MC, Poly F, Guillaumaud N, van Elsas JD, Falcao Salles J (2012) Fluctuations in ammonia oxidizing communities across agricultural soils are driven by soil structure and $\mathrm{pH}$. Front Microbiol 3. doi:10.3389/fmicb.2012.00077

40. Di Giovanni GD, Watrud LS, Seidler RJ, Widmer F (1999) Comparison of parental and transgenic alfalfa rhizosphere bacterial communities using biolog GN metabolic fingerprinting and enterobacterial repetitive intergenic consensus sequence-PCR (ERICPCR). Microb Ecol 37(2):129-139. doi:10.1007/s002489900137

41. Grayston SJ, Wang S, Campbell CD, Edwards AC (1998) Selective influence of plant species on microbial diversity in the rhizosphere. Soil Biol Biochem 30(3):369-378. doi:10.1016/s0038-0717 (97)00124-7

42. Latour X, Corberand T, Laguerre G, Allard F, Lemanceau P (1996) The composition of fluorescent pseudomonad populations associated with roots is influenced by plant and soil type. Appl Environ Microbiol 62(7):2449-2456

43. Ben-Hammouda M, Kremer RJ, Minor HC (1995) Phytotoxicity of extracts from sorghum plant components on wheat seedlings. Crop Sci 35(6):1652-1656

44. Czarnota MA, Paul RN, Dayan FE, Nimbal CI, Weston LA (2001) Mode of action, localization of production, chemical nature, and activity of sorgoleone: a potent PSII inhibitor in Sorghum spp. root exudates. Weed Technol 15(4):813-825
45. Weston LA, Harmon R, Mueller S (1989) Allelopathic potential of sorghum-sudangrass hybrid (sudex). J Chem Ecol 15(6):18551865

46. Coelho MRR, Marriel IE, Jenkins SN, Lanyon CV, Seldin L, O'Donnell AG (2009) Molecular detection and quantification of nifH gene sequences in the rhizosphere of sorghum (Sorghum bicolor) sown with two levels of nitrogen fertilizer. Appl Soil Ecol 42(1):48-53. doi:10.1016/j.apsoil.2009.01.010

47. Hai B, Diallo NH, Sall S, Haesler F, Schauss K, Bonzi M et al (2009) Quantification of key genes steering the microbial nitrogen cycle in the rhizosphere of sorghum cultivars in tropical agroecosystems. Appl Environ Microbiol 75(15):4993-5000. doi:10.1128/aem.02917-08

48. Coelho MRR, Da Mota FF, Carneiro NP, Marriel IE, Paiva E, Rosado AS et al (2007) Diversity of Paenibacillus spp. in the rhizosphere of four sorghum (Sorghum bicolor) cultivars sown with two contrasting levels of nitrogen fertilizer assessed by rpoB-based PCR-DGGE and sequencing analysis. J Microbiol Biotechnol 17(5):753-760

49. Mao Y, Yannarell AC, Mackie RI (2011) Changes in N-transforming Archaea and bacteria in soil during the establishment of bioenergy crops. PLoS One 6(9):12. doi:10.1371/journal.pone.0024750, e24750

50. Culman SW, DuPont ST, Glover JD, Buckley DH, Fick GW, Ferris $\mathrm{H}$ et al (2010) Long-term impacts of high-input annual cropping and unfertilized perennial grass production on soil properties and belowground food webs in Kansas, USA. Agr Ecosyst Environ 137(1-2):13-24, 10.1016/j.agee.2009.11.008

51. Liang C, EdC J, Duncan DS, Jackson RD, Tiedje JM, Balser TC (2012) Soil microbial communities under model biofuel cropping systems in southern Wisconsin, USA: impact of crop species and soil properties. Appl Soil Ecol 54:24-31. doi:10.1016/ j.apsoil.2011.11.015

52. Arriola PE, Ellstrand NC (1996) Crop-to-weed gene flow in the genus Sorghum (Poaceae): spontaneous interspecific hybridization between johnsongrass, Sorghum halepense, and crop sorghum. S Bicolor American J Botany 83(9):1153-1159

53. Skinner K, Smith L, Rice PM (2000) Using noxious weed lists to prioritize targets for developing weed management strategies. Weed Sci 48(5):640-644

54. Warwick SI, Black LD (1983) The biology of Canadian weeds. 61. Sorghum halepense (L.) Pers. Canadian J Plant Sci 63(4):9971014

55. Callaway RM, Thelen GC, Rodriguez A, Holben WE (2004) Soil biota and exotic plant invasion. Nat 427(6976):731-733

56. Reinhart KO, Callaway RM (2006) Soil biota and invasive plants. New Phytol 170(3):445-457. doi:10.1111/j.14698137.2006.01715.x 